\title{
Emergence of Studies into Contemporary International Law with Regard to Rules and Principles for Peace-making: From the Perspective of Diachronic Analyses of Diplomatic Negotiations after the World Wars
}

\author{
Keisuke Minai $^{1}$ \\ ${ }^{1}$ Graduate School of Law, Keio University, Tokyo, Japan \\ Correspondence: Keisuke Minai, Graduate School of Law, Keio University, Tokyo, Japan. E-mail: \\ k_mi_na_i@a6.keio.jp
}

Received: June 6, 2014 Accepted: June 21, 2014 Online Published: July 30, 2014

doi:10.5539/ilr.v3n1p86 URL: http://dx.doi.org/10.5539/ilr.v3n1p86

\begin{abstract}
Although the rules and principles for post-conflict settlement have been frequently examined in recent years, little research has explicitly examined the phenomenon yielding incentive to the contemporary discussions about these rules and principles among international lawyers. That is, what is the formation process of the shift to the peace-making that occurred after the Second World War? This paper examines one of the facets of this phenomenon from the perspective of tracing diplomatic historical facts through diachronic analyses of diplomatic negotiations in the processes of drafting the Versailles Peace Treaty and the Treaty of Peace with Japan, setting up concepts adopted by persons in charge as the barometers. These analyses find that compared to the Versailles Peace Treaty, which had harsh, punitive, and discriminatory characteristics, the peace-making process of the Treaty of Peace with Japan took on a more generous nature tempered by a rigorousness in the legal aspects of the treaty.
\end{abstract}

Keywords: Post-conflict Law, Rules for Peace-making, the Treaty of Peace with Japan, the Versailles Peace Treaty

\section{Introduction}

In recent years, there have been several studies, in different disciplines such as jurisprudence, philosophy, ethics, or political science, ${ }^{1}$ on the rules and principles for post-conflict settlement. ${ }^{2}$ These rules and principles are recognized, to some degree at least, as the objects of inquiry in terms of international law, as can be observed from the following investigations. Stahn, who studies international legal norms for post-conflict peace-making from the perspective of "jus post bellum," the field of the law of armed force, advocates that the rules and principles for conflict settlement are governed by certain norms and standards of international law ${ }^{3}$ including the part of the existing law for managing post-war responsibilities and institutional transformations. ${ }^{4}$ In addition, he maintains that the exploration into these rules and principles has become one of the main preoccupations of

\footnotetext{
${ }^{1}$ Particular research areas referred to as "jus post bellum" or "transitional justice," in which these rules and principles are widely discussed are deemed to have moral, legal, and political dilemmas. On this point, see, Freeman, M., \& Djukić, D. (2008). Jus Post Bellum and Transitional Justice. In C. Stahn, \& J. Kleffner (Eds.), Jus Post Bellum - Towards a Law of Transition from Conflict to Peace (pp. 213-227). The Hague, The Netherlands: T·M·C Asser Press. p. 215.

${ }^{2}$ See, e.g., C. Stahn, \& J. Kleffner (Eds.). (2008). Jus Post Bellum - Towards a Law of Transition from Conflict to Peace. The Hague, The Netherlands: T·M·C·Asser Press; L. May, \& A. Forcehimes (Eds.). (2012). Morality, Jus Post Bellum, and International Law. New York, NY: CUP; L. May, \& E. Edenberg (Eds.). (2013). Jus Post Bellum and Transitional Justice. New York, NY: CUP.

${ }^{3}$ Stahn, C. (2007). 'Jus ad bellum', 'jus in bello' ... 'jus post belum'? - Rethinking the Conception of the Law of Armed Force. EJIL, 17, 921-943. p. 937.

${ }^{4}$ Stahn, C. (2008). The Future of Jus Post Bellum. In C. Stahn, \& J. Kleffner (Eds.), Jus Post Bellum - Towards a Law of Transition from Conflict to Peace (pp. 231-237). The Hague, The Netherlands: T·M·C·Asser Press. p. 232.
} 
international law practice and studies. ${ }^{5}$ On the other hand, in her research on "lex pacificatoria" (law of peacemakers) as the embodiment of normativized practices of conflict resolution, ${ }^{6}$ Bell states that relevant international law is being revised by the outcomes of international conflict resolutions and maintains that this "lex" is the generation of an on-going normative expectation, although not yet recognized as a full-fledged, new legal regime.

Inquiries into the evolving rules and principles for post-conflict settlement often examine post-war reparation and punishment, which are major challenges to the peace-making process. The focus of post-war reparations ${ }^{8}$ has been the coordination of requirements to be enforced on losing states to make restorations to damaged states while allowing the defeated states to remain solvent; how oppressive claims can be restrained. Regarding this, Blum and Lockwood espouse a distributive justice-based reparation scheme that seeks the point of harmony between restoration and burden-sharing of damages, ${ }^{9}$ which suggests a "horizontal expansion" such that third parties should share the duty to repair. ${ }^{10}$ Lazar refutes fault-based, localized distributive justice-based, deterrence-based, or corrective justice-based reparation practices, ${ }^{11}$ and instead, suggests the adoption of global justice-based, or entirely distributive justice-based reparation systems. ${ }^{12}$ Lazar's idea is similar to that found in May's treatises. May contends that those who are most vulnerable must get what is their due first in situations of scarcity ${ }^{13}$ and embraces "meionexia," the concept proposed by Grotius that one should demand less than what is one's due, as evidenced in the treatment of Germany and Japan by the victorious Allies at the end of the Second World War. ${ }^{14}$ Orend provides some variation. His premise is a corrective justice-based scheme, whereby aggressor nations owe duties to repair, but he insists on a balance between the aggressors' available resources and the nature and severity of the acts of aggression, and urges primary disbursement out of the personal wealth of political and military aggressor elites according to principles of proportionality and discrimination; thereby moderating claims for reparation against citizens in aggressor states to avoid the repetition of failure as in the Versailles Peace Treaty. ${ }^{15}$ Ronzitti's counterargument to imposing harsh conditions to extort extreme war

${ }^{5}$ Stahn, supra note 3, p. 922; Stahn, C. (2006). “Jus Ad Bellum," “Jus in Bello," “Jus Post Bellum?” Rethinking the Conception of the Law of Armed Force. ASIL Proceedings, 100, 158-160. p. 160.

${ }^{6}$ The whole range of her study is published in Bell, C. (2008). On the Law of Peace: Peace Agreements and the Lex Pacificatoria. Oxford, OX: OUP.

${ }^{7}$ Bell, C. (2013). Peace Settlements and International Law: from Lex Pacificatoria to Jus Post Bellum. In N. White, \& C. Henderson (Eds.), Research Handbook on International Conflict and Security Law: Jus ad Bellum, Jus in Bello, and Jus post Bellum (pp. 499-546). Cheltenham, UK: Edward Elgar. pp. 499, 503, 544.

${ }^{8}$ With reference to claims at issue or overviews of various studies, see, Kyriakakis, J. (2012). Justice after War: Economic Actors, Economic Crimes, and the Moral Imperative for Accountability after War. In L. May, \& A. Forcehimes (Eds.), Morality, Jus Post Bellum, and International Law (pp. 113-138). New York, NY: CUP. pp. 130-132; Forcehimes, A., \& May, L. (2012). Conclusion. In L. May, \& A. Forcehimes (Eds.), Morality, Jus Post Bellum, and International Law (pp. 250-256). New York, NY: CUP. pp. 254-255; Henderson, C., \& White, N. (2013). Introduction: International Conflict and Security Law. In N. White, \& C. Henderson (Eds.), Research Handbook on International Conflict and Security Law: Jus ad Bellum, Jus in Bello, and Jus post Bellum (pp. 1-3). Cheltenham, UK: Edward Elgar. p. 2; Murphy, C., \& Radzik, L. (2013). Jus Post Bellum and Political Reconciliation. In L. May, \& E. Edenberg (Eds.), Jus Post Bellum and Transitional Justice (pp. 305-325). New York, NY: CUP. p. 307; Bass, G. (2004). Jus Post Bellum. Philosophy \& Public Affairs, 32, 384-412. pp. 408-411; Stahn, supra note 4, pp. 236-237.

${ }^{9}$ Blum, G., \& Lockwood, N. (2013). Earthquakes and Wars: The Logic of International Reparations. In L. May, \& E. Edenberg (Eds.), Jus Post Bellum and Transitional Justice (pp. 178-216). New York, NY: CUP. pp. 206-208.

${ }^{10}$ Ibid., pp. 178-179.

${ }^{11}$ Lazar, S. (2012). Skepticism about Jus Post Bellum. In L. May, \& A. Forcehimes (Eds.), Morality, Jus Post Bellum, and International Law (pp. 204-222). New York, NY: CUP. pp. 205-211.

12 Ibid., p. 222.

${ }^{13}$ May, L. (2012). Reparations, Restitution, and Transitional Justice. In L. May, \& A. Forcehimes (Eds.), Morality, Jus Post Bellum, and International Law (pp. 32-48). New York, NY: CUP. p. 36.

${ }_{14}$ Ibid., pp. 35-36, 43; May, L., \& Edenberg, E. (2013). Introduction. In L. May, \& E. Edenberg (Eds.), Jus Post Bellum and Transitional Justice (pp. 1-25). New York, NY: CUP. pp. 6-7.

${ }_{15}$ Orend, B. (2000). Jus Post Bellum. Journal of Social Philosophy, 31, 117-137. pp. 124-125; Orend, B. (2008). Jus Post Bellum: a Just War Theory Perspective. In C. Stahn, \& J. Kleffner (Eds.), Jus Post Bellum - Towards a Law of Transition from Conflict to Peace (pp. 31-52). The Hague, The Netherlands: T·M·C·Asser Press. p. 47. 
reparations from defeated states places particular emphasis on the protection of human rights in war reparation and suggests that victorious powers renounce war damages in whole or part in peace treaties. ${ }^{16}$ Ronzitti takes the position that reparation is anchored in legal standards from the perspective of international law. ${ }^{17}$ Stahn agrees as he suggests that the emergence of rules that prohibit indiscriminate punishment of a people through excessive reparation claims is detectable in contemporary international law and that the humanization of reparation is emerging as a legal rule in post-conflict law. ${ }^{18}$

The avoidance of extravagant retribution by amnesty for reconciliation (restoration) ${ }^{19}$ is also observable in the restraints on war-related punishment. ${ }^{20}$ Lazar, regarding goals to relieve victims' suffering and build peace, contests the relative magnitude of directing resources toward retribution and explicitly describes amnesty as the foothold of this thought process. ${ }^{21}$ Pensky recognizes the principle of retribution by referring to the possibility that actions that make due prosecution of suspected war criminals impossible constitute violations of law in post-war peace-making, although he agrees that amnesty is of great benefit to security and reconciliation. ${ }^{22}$ Stahn's perspective of international law supports adapting post-conflict responsibility with the needs of peace in the area of criminal responsibility to orient a combined model for justice and reconciliation that incorporates amnesty as one legal rule of post-conflict law. ${ }^{23}$

There have been observations that the comparisons of the practices of crafting peace after the First and Second World Wars provide new aspects of studies with respect to the rules and principles for post-conflict settlement. May and Edenberg recognize that the treatment of Germany and Japan after the Second World War has set the stage for discussions about the rules for peace-making, significantly educate scholars about how best to understand these rules, and encourage these scholars to highlight the similarities in recent literature about these rules. ${ }^{24}$ Similarly, Majima has underlined the vital role of the American occupation of Japan after the Second World War purporting it to be one of the most successful occupations. ${ }^{25}$ In contrast, the Versailles Peace Treaty, after the First World War, has been criticized for failing to construct principles for post-conflict peace building, ${ }^{26}$ as it adopted a bargaining process among the victors for the rights and obligations of the vanquished. ${ }^{27}$ The

${ }^{16}$ Ronzitti, N. (2013). Reparation and Compensation. In N. White, \& C Henderson (Eds.), Research Handbook on International Conflict and Security Law: Jus ad Bellum, Jus in Bello, and Jus post Bellum (pp. 638-659). Cheltenham, UK: Edward Elgar. pp. 644-646.

${ }^{17}$ Ibid., p. 658.

${ }^{18}$ Stahn, supra note 3, p. 939.

${ }^{19}$ However, Orend merely underscores, on the basis of the just war theory, the necessity of punishing war criminals for transgressions of jus ad bellum or jus in bello from the perspective of deterrent effects, rehabilitation, and satisfaction of victims. In this regard, see, Orend, Jus Post Bellum, supra note 15, pp. 123-124, 127; Orend, Jus Post Bellum: a Just War Theory Perspective, supra note 15, p. 41.

${ }^{20}$ With respect to introductions positioning punishment as one of the principles for post-war peace settlement, see, Rodin, D. (2008). Two Emerging Issues of Jus Post Bellum: War Termination and the Liability of Soldiers for Crimes of Aggression. In C. Stahn, \& J. Kleffner (Eds.), Jus Post Bellum - Towards a Law of Transition from Conflict to Peace (pp. 53-75). The Hague, The Netherlands: T·M·C·Asser Press. p. 62; Williams, Jr., R., \& Caldwell, D. (2006). Jus Post Bellum: Just War Theory and the Principles of Just Peace. International Studies Perspectives, 7, 309-320. p. 318.

${ }^{21}$ Lazar, supra note 11, pp. 211-214, 221.

${ }^{22}$ Pensky, M. (2013). Jus Post Bellum and Amnesties. In L. May, \& E. Edenberg (Eds.), Jus Post Bellum and Transitional Justice (pp. 152-177). New York, NY: CUP. pp. 153-154.

${ }^{23}$ Stahn, supra note 3, pp. 940-941. Amnesty may not be necessarily restricted to less serious crimes. For example, since the Treaty of Peace with Japan (1951), France and Algeria have determined not to try individuals who had committed crimes against humanity in the Evian Agreement of 1962. Similarly, India and Bangladesh decided not to prosecute Pakistanis for crimes against humanity in 1973 after the Bangladesh war. See, Scharf, M. (1996). The Letter of the Law: the Scope of the International Legal Obligation to Prosecute Human Rights Crimes. Law \& Contemp. Probs., 59, 41-62. p. 57.

${ }^{24}$ May, \& Edenberg, supra note 14, pp. 14-15.

${ }^{25}$ Majima, S. (2013). Just Military Occupation? A Case Study of the American Occupation of Japan. In L. May, \& E. Edenberg (Eds.), Jus Post Bellum and Transitional Justice (pp. 26-43). New York, NY: CUP. p. 27.

${ }^{26}$ Orend, Jus Post Bellum: a Just War Theory Perspective, supra note 15, pp. 36-37.

${ }^{27}$ Stahn, C. (2008). Jus Post Bellum: Mapping the Discipline(s). In C. Stahn, \& J. Kleffner (Eds.), Jus Post Bellum - Towards a Law of Transition from Conflict to Peace (pp. 93-112). The Hague. The Netherlands: T·M·C·Asser Press. pp. 96-97. 
results of the Versailles Peace Treaty have been called the first punitive peace since the Middle Ages, ${ }^{28}$ accused of destroying advances in the practice of peace-making and its underlying concepts from before the First World War. ${ }^{29}$ The Versailles Peace Treaty constituted a return to the concept of just peace despite a consequence of failure in an absolute return to this concept through this opportunity. ${ }^{30}$ Hence, the concept that was the base for peace negotiations following the Second World War and that presented an incentive for contemporary investigations as to rules and principles for post-war peace, can be extrapolated that this concept inevitably differs greatly from the one on which the Versailles Peace Treaty was built.

Two major foci of post-war reparation and punishment notably conform to this incentive. In the Treaty of Peace with Japan, there are marked efforts to create more humane and fair legal effects of these foci, evidenced by the restraint of pitiless claims for damages by allowing Japan to make reparation from services, the avoidance of new war-crime prosecutions after the declaration of peace, and measures commuting some criminal sentences. In the march to recovery from times when only victorious belligerents with just causes were entitled to punish unjust enemies and to make claims for reparations, ${ }^{31}$ modern positivism restricted all belligerents from punishing enemies and raising claims for reparation of damages by explicitly or implicitly inserting amnesty clauses into all peace treaties. ${ }^{32}$ However, from the late nineteenth century, peace treaties were written with increasingly punitive and discriminatory characteristics culminating in the Versailles Peace Treaty. ${ }^{33}$ Lauterpacht noted that indemnity against war costs as suggested in positivism was supplanted by a new concept of monetary reparations for waging war. ${ }^{34}$ Fenwick describes the trial and punishment of the German ex-Kaiser and individual members of the German armed forces as a striking exception to the customary amnesty clauses founded in positivism. ${ }^{35}$ In the Treaty of Peace with Japan, the spirit of reconciliation was observed in the reduction of severe and superfluous claims for reparations and punishment.

A great deal of effort has been spent to determine the rules and principles for post-conflict peace-making and the legal nature of these rules. However, little is known about a concrete phenomenon that yielded incentive to the discussions in the disciplines of international law. To put it otherwise, how can the process of concrete conversion to the peace building after the Second World War be portrayed? ${ }^{36}$ This current state of inquiries

${ }^{28}$ Lesaffer, R. (2004). Introduction. In R. Lesaffer (Ed.), Peace Treaties and International Law in European History - From the Late Middle Ages to World War One (pp. 1-6). Cambridge, CB: CUP. p. 4.

${ }^{29}$ Steiger, H. (2004). Peace treaties from Paris to Versailles. In R. Lesaffer (Ed.), Peace Treaties and International Law in European History - From the Late Middle Ages to World War One (pp. 59-99). Cambridge, CB: CUP. p. 83.

${ }^{30}$ Lesaffer, R. (2012). Peace treaties and the Formation of International Law. In B. Fassbender, \& A. Peters (Eds.), The Oxford Handbook of the History of International Law (pp. 71-94). Oxford, OX: OUP. p. 91. The cause of this failure may be that, as Arthur Nussbaum acutely noted, the natural-law doctrine of the twentieth century "is merely the inevitable reaction to the cruder from (sic) of nineteenth century positivism.” See, Nussbaum, A. (1954) A Concise History of the Law of Nations (rev ed.). New York, NY: Macmillan. p. 277.

${ }^{31}$ See, e.g., Victoria, F. (1696/1917). De Indis Relectio Posterior, sive De Iure Belli Hispanorum in Barbaros. In F. Victoria, De Indis et de Ivre Belli Relectiones (J. P. Bate, Trans.). Washington, D.C.: the Carnegie Endowment for International Peace. paras. 17, 19, 46, 59.

32 Zayas, A. (1992). Amnesty Clause. In P. Macalister-Smith et al. (Eds.), Encyclopedia of Public International Law (vol. 1, pp. 148-151). Amsterdam: North-Holland. p. 148; Grewe, W. (1982). Peace Treaties. In R. Dolzer et al. (Eds.), Encyclopedia of Public International Law (vol. 4, pp. 102-110). Amsterdam: North-Holland. pp. 103, 109; Lesaffer, R. (2004). Peace treaties from Lodi to Westphalia. In R. Lesaffer (Ed.), Peace Treaties and International Law in European History - From the Late Middle Ages to World War One (pp. 9-44). Cambridge, CB: CUP. pp. 38-40; Duchhardt, H. (2004). Peace treaties from Westphalia to the Revolutionary Era. In R. Lesaffer (Ed.), Peace Treaties and International Law in European History - From the Late Middle Ages to World War One (pp. 45-58). Cambridge, CB: CUP. p. 49; Steiger, supra note 29, p. 84; Lesaffer, supra note 30, pp.77, 89.

${ }^{33}$ Kleffner, J. (2012). Peace Treaties. In K. Kaiser et al. (Eds.), The Max Planck Encyclopedia of Public International Law (vol. 8, pp. 104-111) Oxford, OX: OUP. p. 105.

${ }^{34}$ Lauterpacht, H. (Ed.). (1935). Oppenheim's International Law: A Treatise (vol. 2) (5th ed.). London: Longmans. pp. 475-476, para. 269a. See also, Steinkamm, A. (1982). War Damages. In R. Dolzer et al. (Eds.), Encyclopedia of Public International Law (vol. 4, pp. 298-303). Amsterdam: North-Holland. pp. 298, 300.

${ }^{35}$ Fenwick, C. (1965). International Law (4th ed.). New York: Appleton-Century-Crofts. pp. 758-759.

${ }^{36}$ Stahn explicates inclusively that there are certain macro-changes from a statist and national-interest driven conception of conflict termination to a pluralist and problem-solving approach to peace-making. On this point, see, Stahn, supra note 3, p. 941. This elucidation illuminates the clues to discuss contemporary peace-making to some extent. However, this explanation merely describes "macroscopic" conversion of the concept of peace-making; therefore cannot be deemed to dilate conversion as a concrete phenomenon in peace building 
weakens the revealing guidelines for empirical research ${ }^{37}$ based on an inductive approach ${ }^{38}$ accorded with the incentive.

In this article, the author attempts to illuminate the phenomenon constructing the incentive with a view to contributing to facilitate empirical research on the rules and principles for peace-making. These rules and principles are considered to embrace peace agreements; ${ }^{39}$ accordingly the author can address one of the facets of the phenomenon by approaching these from the perspective of peace treaties. Besides, this phenomenon should be the historical fact that certain conversion in peace settlement has emanated; and this fact, of course, comprehends diplomatic historical facts. Thus, tracing these facts in terms of diachronic analyses of diplomatic negotiations can facilitate shedding light on one of the facets of the phenomenon. A barometer to observe conversion as for peace-making in these diplomatic historical facts needs to be the one that can synthetically measure the volition of persons in charge of peace treaty negotiations and extrapolate what legal effects emerge form any specific peace treaty. Accordingly, it is appropriate to set up attitudes shaped by the congeries of intents that emerged in the processes of diplomatic negotiations as the barometers. Thus the author adopts, as them, concepts in international law and politics that are "harsh peace" and "soft peace" defined as a pitiless/liberal attitude to conclude a peace treaty connoting oppressive/lenient legal effects toward the other party of war. ${ }^{40}$ The divide between harshness and softness of these concepts can be derived from a comparative examination, from the standpoint of legal effects, of these concepts and old concepts of peace in traditional international law (see the next chapter). Furthermore, concentration on the principles affecting reparation and punishment that mirror the incentive is an inevitable limitation since the objective of this paper is to further empirical research along the lines of this incentive. To recapitulate, the author examines one of the facets of the phenomenon, upon which contemporary discussions among international lawyers about the rules and principles for peace-making depend, by means of diachronic analyses of diplomatic negotiations in the processes of drafting the provisions as to reparation and punishment in the Versailles Peace Treaty and the Treaty of Peace with Japan, fixing harsh peace and soft peace as the barometers.

\section{Prehistory of the Dichotomy between Harsh Peace and Soft Peace}

\subsection{Just War Theory - Jus Victoriae}

This chapter provides an overview of doctrines, focusing on concepts of peace and their legal effects on punishment and reparation in international jurisprudence before the birth of the Versailles Peace Treaty, where the opposition between harsh peace and soft peace was observable. This overview provides the basis for comparative analysis and consideration of the divide between harshness and softness of these pair wise concepts.

Jus victoriae or the laws of the victor ${ }^{41}$ as addressed in this section was the legal norm that inflicted punishment on the unjust conquered or granted the right to claim reparation to the just victor. In other words, based on a discriminate concept of peace which inequitably treated belligerents whether they had just causes or not, jus victoriae formed only the scope of rights for the just belligerent. Protagonists for jus victoriae were entirely heirs of scholastic just war doctrine.

Vitoria, one of the scholars of scholasticism, explained by citing Augustine that the aim of war was to secure

after the Second World War that provides incentive for the discussions of international legal rules and principles for peace.

${ }^{37}$ See, Stahn, supra note 27, p. 109.

${ }^{38}$ See, Neff, S. (2008). Conflict Termination and Peace-making in the Law of Nations: A Historical Perspective. In C. Stahn, \& J. Kleffner (Eds.), Jus Post Bellum - Towards a Law of Transition from Conflict to Peace (pp. 77-91). The Hague, The Netherlands: T·M·C·Asser Press. pp. 90-91.

39 Österdahl, I. (2012). Just War, Just Peace and the Jus Post Bellum. Nordic J Int'l L, 81, 271-294. pp. 271-272, 289.

${ }^{40}$ Harsh peace and soft peace are proposed by Yasuaki Onuma, professor emeritus of international law at the University of Tokyo, as the concepts invoked throughout the processes of peace settlement after the First and the Second World Wars. See, Onuma, Y. (1975). Sensō Sekininron Josetsu [Prolegomena to the Responsibility for War]. Tokyo: Tokyo Daigaku Shuppankai. pp. 40, 41, 46, 63, 66, 222, 228, 237, 245, 247 (in Japanese). Onuma regards these concepts as rudimentary attitudes about peace. See, ibid., p. 63. Furthermore, Chihiro Hosoya, who was the professor emeritus of international politics at the University of Hitotsubashi, adopted a similar taxonomy for the process of drafting the Treaty of Peace with Japan. See, Hosoya, C. (1984). San Furanshisuko Kōwa he no Michi [The Road to the Peace of San Francisco]. Tokyo: Chuo Koron Sha. pp. 80, 84, 90, 91, 102, 162 (in Japanese).

${ }^{41}$ See, e.g., Neff, supra note 38, pp. 77-81. 
peace. ${ }^{42}$ Thus, from a scholastic just war theory, Vitoria considered that war should be just and lawful when it was waged with the object of recovering just peace. ${ }^{43}$ Accordingly, in an offensive war $^{44}$ a just party demanding revenge for serious wrongs done ${ }^{45}$ should be allowed a means of punishment for just causes. ${ }^{46}$ This theory is based on the concept of punitive war, ${ }^{47}$ which positioned a prince who fought a just war and won victory as a judge inflicting punishment on the unjust. ${ }^{48}$

Vitoria classified just methods of war into two categories of law, jus in bello and jus post bellum. ${ }^{49}$ For the latter, Vitoria gave consideration only to the rights and duties of a just victor, or jus victoriae, in conformance with the hypothesis that the one who had just causes on his side should be envisaged as the conqueror, while the one who provoked unjust war would be the vanquished. ${ }^{50}$

First, with respect to the principles for punishment, Vitoria contended that it was lawful to inflict punishment on an unjust enemy for the wrongs he had done, even after victory had been won and peace had been secured. ${ }^{51}$ It was even lawful for the just victor to kill the guilty. ${ }^{52}$ Additionally, if the just party had the end of procuring peace and security, it was lawful and expedient to kill all the guilty of the unjust conquered. ${ }^{53}$ By these pretensions, it can be ascertained that only the victor who had just causes was granted the right to inflict extremely pitiless punishment on unjust losers according to a discriminate concept of peace derived from the just war doctrine and concept of punitive war.

Second, in the principles for reparation, Vitoria claimed that it was lawful for the just victor to utilize enemy property as all damages wrongfully caused by an unjust enemy; ${ }^{54}$ that is, a conqueror could seize an enemy's entire property captured in a just war to the amount which provided satisfaction for the things that had been wrongfully seized. ${ }^{55} \mathrm{~A}$ just victor demanding reparation could seize movables and immovables originally possessed by unjust enemies only if he was subject to equity. ${ }^{56}$ In addition, the just belligerent could impose a tribute on conquered enemies as reparation and punishment. ${ }^{57}$ This is one of the principles in jus victoriae, which discriminately granted the right to claim reparation only to the one who had just causes on his side.

Suárez also dealt in a discriminate concept of peace and jus victoriae in almost the same way as Vitoria. First, from scholastic just war doctrine, Suárez followed the concept of punitive $\operatorname{war}^{58}$ by regarding war as a means of

${ }^{42}$ Victoria, supra note 31 , p. 167 , para. 1.

${ }^{43}$ Ibid., p. 172, para. 18.

${ }^{44}$ Ibid., pp. 166-167, para. 1.

${ }^{45}$ Ibid., pp. 170-171, paras. 13, 14.

${ }^{46}$ Mendizábal, A. (1947). On Everlasting Values of the Spanish School of Natural Law (F. De Vitoria). In P. Sayre (Ed.), Interpretations of Modern Legal Philosophies: Essays in Honor of Roscoe Pound (pp. 498-520). New York, NY: OUP. p. 514.

${ }^{47}$ Based on the concept of punitive war, a nation with just causes can commence war to punish foreign countries, which caused the nation damage, by means of applying a domestic constitution, by which a nation can inflict punishment on an individual who is under the jurisdiction of this nation, to the sphere of international armed conflicts. See, Blane, A., \& Kingsbury, B. (2010). Punishment and the jus post bellum. In B. Kingsbury, \& B. Straumann (Eds.), The Roman Foundations of the Law of Nations: Alberico Gentili and the Justice of Empire (pp. 241-265). New York, NY: OUP. pp. 249-250, 256-257.

${ }^{48}$ Victoria, supra note 31, p. 187, para. 60.

49 Ito, F. (1973). The Peace Ideas of Vitoria, Suarez and Grotius. In R. Weiler, \& V. Zsifkovits (Eds.), Unterwegs zum Frieden: Beitr. z. Idee

u. Wirklichkeit d. Friedens (pp. 205-217). Wien: Herder. p. 206.

${ }^{50}$ Mendizábal, supra note 46, p. 515.

${ }^{51}$ Victoria, supra note 31, p. 172, para. 19

${ }^{52}$ Ibid., p. 182, para. 46.

${ }^{53}$ Ibid., p. 183, para. 48.

${ }^{54}$ Ibid., p. 171, para. 17.

55 Ibid., p. 184, para. 50.

${ }^{56}$ Ibid., pp. 184, 185, paras. 51, 54, 56.

${ }^{57}$ Ibid., p. 186, para. 57.

${ }^{58}$ Suárez, as with Vitoria, explained the concept of punitive war from the point of jurisdiction, stating that an unjust belligerent would be subject to the jurisdiction of a just victor and deserving of punishment by reason of having committed some wrong. Suárez, F. (1621/1944). 
attaining real and secure peace ${ }^{59}$ and as an institution in place of a tribunal administering just punishment. ${ }^{60}$ Second, Suárez divided the proper mode of war into three periods: inception of war, prosecution of war, and period after victory. ${ }^{61}$ Presupposing that a just belligerent gained victory, he described the questions surrounding punishment and reparation.

As one of two requirements with regard to an injury inflicted or justification for a declaration of war, Suárez stated that offenders belonging to an unjust belligerent could be duly punished. ${ }^{62}$ More specifically, Suárez maintained that certain guilty individuals among the unjust enemy could be justifiably put to death after the war had been entirely ended, if all the penalties inflicted upon the unjust conquered state as reparation seemed insufficient in view of the gravity of the wrong. ${ }^{63}$ In this vein, the privilege to extremely penalize opponents could be given only to a just triumphant belligerent as with Vitoria.

Suárez also required that reparation for losses suffered should be made out to the injured, just party, ${ }^{64}$ stating that a just prince was allowed to inflict upon the unjust conquered state such losses as were sufficient for a just punishment and satisfaction, and reimbursement for all losses suffered.$^{65}$ He also stressed inclusion of all losses by the unjust state in question throughout the war such as the deaths of men and conflagrations in computing the sum required for reparation. ${ }^{66}$ By these descriptions, Suárez demonstrated the legal effect that only the just victor could win the right to claim reparation, so that he implied founding his principles upon a discriminate concept of peace.

From the principles common to Vitoria and Suárez on punishment and reparation, it could be concluded that the norms of jus victoriae based on a discriminate concept of peace allowed imposing harsh punishment, and seriously burdensome obligation to pay reparation discriminately upon the vanquished, and therefore unjust parties. Thus, a concept known as harsh peace in the drafting process of the Versailles Peace Treaty, allowing the construction of a peace treaty with rigorous legal effects for defeated nations, correlated profoundly with jus victoriae derived from just war theory based on a discriminate concept of war because the Versailles Peace Treaty has been generally interpreted as the one which yielded conversion from an indiscriminate concept of war into a discriminate one. Understood in this way, legal effects of jus victoriae can serve as criterion or baseline to determine the harshness of harsh peace.

\subsection{Dualism - Jus Victoriae and Jus Ad Pacem}

While scholastics dwelled upon jus victoriae, historical and empirical research on treaty practices were propagated in tandem with the development of humanistic methodology. There were international lawyers who treated jus ad pacem ${ }^{67}$ specifically the laws of peace drawing on an indiscriminate concept of peace as well as jus victoriae according to the taxonomy of the manner of terminating war or of law on which the doctrines of war were built.

Gentili should be regarded as one of those lawyers who, by claiming peace as the purpose of war along with Vitoria and Suárez, ${ }^{68}$ deemed that war was regulated by divine law, natural law, or jus gentium without explicit differentiation ${ }^{69}$ and defined war as a just contest of arms. ${ }^{70}$ However, the term "just war" in Gentili's context,

De Triplici Virtute Theologica Fide, Spe et Charitate disputatio XIII. In F. Suárez, Selections from Three Works of Francisco Suárez, S.J. (G.

L. Williams et al., Trans.). Washington, D.C.: the Carnegie Endowment for International Peace. ch. 4, para. 1.

${ }^{59}$ Ibid., ch. 1, para. 3.

${ }^{60}$ Ibid., ch. 4, para. 5.

${ }^{61}$ Ibid., ch. 7, para. 1.

${ }^{62}$ Ibid., ch. 4, para. 4.

${ }^{63}$ Ibid., ch. 7, para. 7.

${ }^{64}$ Ibid., ch. 4, para. 4.

${ }^{65}$ Ibid., ch. 7, para. 7.

${ }^{66}$ Ibid.

${ }^{67}$ Note that the term "jus ad pacem" was proposed by Randall Lesaffer.

${ }^{68}$ Gentili, A. (1612/1933). De Iure Belli (vol. 1) (J. C. Rolfe, Trans.). Washington, D.C.: the Carnegie Endowment for International Peace. ch. 5, p. 29.

${ }^{69}$ Ibid., ch 7, p. 35 . 
differed from the sense scholastics put forward. For Gentili righteous war meant that executed by a regular army, a regular soldier, and a regular leader with a full complement of arms, with the result that "just" signified not only what was lawful but also what was perfect in all its parts. ${ }^{71}$ Therefore, presupposing that both sides could be called just by quoting Baldus, ${ }^{72}$ Gentili maintained that the laws of war were indiscriminately applied to both parties whether they contended justly. ${ }^{73}$

According to Gentili, it could be concluded that not only jus in bello but also jus post bellum should be equally applied to both belligerents, since all parties of war were to acquire application of the laws of war. Gentili classified jus post bellum into two systems for the termination of war: jus victoriae would be applied only to the victor when one side had won a triumph, while jus ad pacem would be applied to both sides that had not won apparent victories, but had concluded a peace treaty. ${ }^{74}$

The norms of jus victoriae, which Gentili adopted, granted a victorious state the power to inflict punishment and demand reparation as in old just war doctrine. ${ }^{75}$ From the context of Gentili's treatise, for punishment, the outcome of war did not determine the objective justice of the victor, but allowed the victor to vindicate his contentions and inflict punishment upon defeated nations, as if they were in the wrong. ${ }^{76}$ It was given that the recipient of punishment was presumed to be a conquered party. ${ }^{77}$ Consequently, Gentili permitted the conqueror to penalize individuals of the conquered with the objectives of consolation for the injured party, freedom for the future from anxiety caused by the person who was punished, and preventing the one who had committed the fault from profiting by it. ${ }^{78}$ Turning to the matter of reparation, Gentili claimed that the framework of a domestic forum of civil and criminal cases where the loser should refund the costs to the victor was applied to international armed conflicts; and that the triumphant nation was awarded the power to decide who had just causes on his side. ${ }^{79}$ By this theoretical justification, only the victorious party could exact reparation for expenses incurred and losses suffered during the war.

Jus ad pacem, the secondary form of Gentili's jus post bellum, was the legal norm applied when a peace treaty was concluded between both belligerents who did not win respective victories. ${ }^{80}$ Gentili's distinction between jus ad pacem and jus victoriae reflected the existing reality of intra- and outer-European practices. ${ }^{81}$ An analysis of jus ad pacem reveals that peace treaties among European powers were regarded as political compromises, were silent regarding the just causes of both belligerents, and were concluded on the assumption that both parties had the right to commence war. ${ }^{82}$ As a result, peace treaties among European nations almost always had an amnesty clause ${ }^{83}$ that prohibited demands for reparation for losses or damages suffered and inflicting

${ }^{70}$ Ibid., ch 2, p. 12.

${ }^{71}$ Ibid., ch 2, pp. 13, 14.

72 Ibid., ch 6, pp. 31, 32.

73 Ibid., ch 6, p. 33.

${ }^{74}$ Lesaffer, R. (2010). Alberico Gentili's jus post bellum and Early Modern Peace Treaties. In B. Kingsbury, \& B. Straumann (Eds.), The Roman Foundations of the Law of Nations: Alberico Gentili and the Justice of Empire (pp. 210-240). New York, NY: OUP. p. 224. See also, Gentili, A. (1612/1933). De Iure Belli (vol. 3) (J. C. Rolfe, Trans.). Washington, D.C.: the Carnegie Endowment for International Peace. ch. 1, para. 473 , p. 290.

${ }^{75}$ See, Gentili, supra note 68 , ch. 6, p. 33.

${ }^{76}$ Lesaffer, supra note 74, p. 225.

${ }^{77}$ Blane, \& Kingsbury, supra note 47, p. 258.

${ }^{78}$ Gentili, supra note 74 , ch. 2, paras. 481-482, p. 295; ch. 13, para. 576, p. 353.

79 Ibid., ch. 3, paras. 485-487, pp. 298-299.

${ }^{80}$ Ibid., ch. 14, para. 589, p. 360.

${ }^{81}$ Lesaffer, supra note 74, p. 225.

${ }^{82}$ Ibid.

${ }^{83}$ In actuality, as taken up later, Gentili did not refer to the matter of an amnesty clause. However, Gudelinus, who was almost contemporary with Gentili, brought the customary practices and the law of peace treaties into the context of jurisprudence on the basis of his familiarity with treaty practice, explained them according to the philological-historical method of the humanists, and wrote a treatise on issues from current peace-treaty practices. In this treatise, Gudelinus evidenced the fact that for a long time, an amnesty clause had always been included in peace treaties by means of offering examples from Greek and Roman antiquity. See, Lesaffer, R. (2002). An Early Treatise on Peace 
punishment for all war crimes. ${ }^{84}$ For jus victoriae, this legal norm was applied to the relationships between European powers and indigenous peoples in the East and West Indies. ${ }^{85}$

With respect to jus ad pacem, Gentili enumerated provisions about the laws, liberty, territory, places, buildings, friendships, arms, armies, fleets, citadels, and garrisons as clauses normally found in peace treaties. ${ }^{86}$ However, he overlooked important aspects of peace treaties such as amnesty clauses, which were most relevant to the principles for punishment and reparation. ${ }^{87}$

Grotius followed scholastic just war doctrine by regarding peace as the ultimate goal of war, ${ }^{88}$ but he definitively dissociated jus gentium as jus humanum from jus naturae and jus divinum, and made the meaning of the justice of war in jus gentium distinct from that based on just war doctrine, with the result that he advocated a theory where both belligerents could wage just war in terms of external effects. Despite this differentiation between jus naturae and jus voluntarium, he nevertheless categorized jus post bellum not according to the systems of law where the concepts of war depended, but according to the distinction between when one side was victorious and when a peace treaty was concluded, similar to Gentili.

With regard to just war, Grotius stated that a war was often called just not from its cause, but because of certain peculiar legal consequences, ${ }^{89}$ so he suggested that the word "just" in relation to these legal effects meant "formal" or "legal" for public war grounded on jus gentium. ${ }^{90}$ As a result of adopting the concept of public war, Grotius admitted that a war could be a just war, namely a public war, from the viewpoint of either side. ${ }^{91}$ This was a different perspective from Gentili who merely gave the change of the meaning of just war in jus naturae, where Grotius advanced two mutually diverse concepts of just war: just war in jus naturae and public war in jus gentium.

However, consider that Grotius, bearing in mind a discriminate concept of peace in jus naturae, dealt with questions of jus post bellum according to the classification of how to terminate war in the same manner as Gentili. Thus, after surrendering, the vanquished should acquiesce to punishment where their subjects would be killed if their offenses deserved this fate. ${ }^{92}$ Persons who performed war unjustly from the perspective of jus naturae $^{93}$ should make good the wrong done, even if they had undertaken a public war as in jus gentium. ${ }^{94}$ These descriptions should be interpreted to be germane to jus victoriae, which provided the right of the just victor to punish and claim reparation.

In the second instance, when a peace treaty was concluded, Grotius contended that the interpretation of peace treaties should be assumed to put both parties on equal footing as much as possible with regard to the justice of the war, since it was not customary for the parties to arrive at peace treaties by confessions of wrongs; although in principle, the interpretation of ambiguous clauses should be directed to the end that the side who had just causes of war could recover for damages. ${ }^{95}$ Grotius did not classify jus post bellum as to the distinction between jus naturae and jus gentium since he also applied the just war doctrine to the norms for peace treaties by dealing

Treaties: Petrus Gudelinus between Roman Law and Modern Practice. J Legal Hist, 23, 223-252.

${ }^{84}$ Lesaffer, supra note 74, p. 225.

${ }^{85}$ Ibid., p. 226.

${ }^{86}$ Gentili, supra note 74 , ch. 15 , para. 600 , p. 367.

${ }^{87}$ Lesaffer, supra note 74, p. 238.

${ }^{88}$ Grotius, H. (1646/1925). De Jure Belli ac Pacis (vol. 1) (F. W. Kelsey et al., Trans.). Washington, D.C.: the Carnegie Endowment for International Peace. ch. 1-I, p. 33.

${ }^{89}$ Grotius, H. (1646/1925). De Jure Belli ac Pacis (vol. 3) (F. W. Kelsey et al., Trans.). Washington, D.C.: the Carnegie Endowment for International Peace. ch. 3-I-1, p. 630.

${ }^{90}$ Grotius, supra note 88, ch. 3-IV-1, p. 97.

${ }^{91}$ Grotius, H. (1646/1925). De Jure Belli ac Pacis (vol. 2) (F. W. Kelsey et al., Trans.). Washington, D.C.: the Carnegie Endowment for International Peace. ch. 23-XIII-5, p. 566.

92 Grotius, supra note 89 , ch. 20-L, p. 826.

${ }_{93}$ See, Grotius, supra note 91, ch. 17-I, p. 430.

${ }^{94}$ Grotius, supra note 89, chs. 10-III, -IV, pp. 718-719.

${ }^{95}$ Ibid., chs. 20-XI, -XII, p. 809. 
with the equity of the justice of the war in relation to the interpretation of peace treaties without applying jus gentium. In conformity with this methodology for interpreting peace treaties, Grotius said that in every peace treaty it should be considered settled that there should be no liability on account of the damage, which had been caused by the war if no other agreement had been made. ${ }^{96}$ Accordingly, he advocated the principle of no reparation. On punishment, Grotius deemed that the canon of the right to inflict punishment should not be remitted by peace treaties as a rule. ${ }^{97}$ However, he suggested an intent to applaud an amnesty for punishment by virtue of quoting one of the sayings of Isocrates, that in peace treaties it was not fitting to bring up former wrongs. ${ }^{98}$ Grotius said that peace with sufficient safety was well established by pardoning offenses. ${ }^{99}$

Unlike these two dualists, Wolff established a clear distinction between the natural and voluntary law of nations, and categorized jus post bellum according to this distinction. He advanced the dualism of jus victoriae based on a discriminate concept of peace in the natural law of nations and jus ad pacem based on an indiscriminate concept of peace in the voluntary law of nations.

Wolff's theory of war in the natural law of nations went with the tide of the traditional just war doctrine, so that he inevitably adopted a discriminate concept of peace. Accordingly, as with the other just war theorists, Wolff studied jus victoriae, expounding the powers of the just belligerent to claim reparation ${ }^{100}$ and inflict punishment ${ }^{101}$ on the unjust for waging unjust war.

Wolff's theory of war in the voluntary law of nations presupposed the fact that each nation was allowed to follow its own judgment in determining its actions, as long as it did nothing contrary to the rights of another since all nations were free by nature. He derived the theorem that each belligerent should be allowed to follow its own opinion when each of them claimed it had just causes for war, with the result that Wolff stated that by the voluntary law of nations, in so far as effects, war was to be considered as just on either side. ${ }^{102}$ Additionally, he highlighted that jus victoriae on the basis of a discriminate concept of peace could not be applied to the conclusion of a peace treaty, for peace treaties could be made not in a way that one who had just causes completely acquired his demands, but by way of compromise by all parties of the war. ${ }^{103}$ Thus, Wolff developed jus ad pacem where the legal effects of peace treaties were determined based on an indiscriminate concept of peace, treating both sides evenly whether any of them had just causes. First, Wolff urged the principle of no punishment on each of the belligerents for wrongs done because of the war. More specifically, Wolff defined amnesty as complete and lasting forgetfulness of wrongs and offenses previously committed, and set its legal effect that no one could be accused or punished for such acts. ${ }^{104}$ He regarded amnesty to be contained in every treaty of peace, even if there was no agreement for it. ${ }^{105}$ Second, Wolff stated that, in a treaty of peace, there should be no action for the recovery of losses, which had been caused in war unless there had been an agreement otherwise. ${ }^{106}$ In other words, Wolff's jus ad pacem established the principle of no reparation among all parties of a war.

In this way, Wolff introduced jus ad pacem based on an indiscriminate concept of peace that did not treat each of the belligerents discriminately whether one of them had just causes. This was a result of a concept of war in the voluntary law of nations that did not determine who had had just causes. Thus, Wolff adopted the principles of no punishment and no reparation as manifestations of equal treatment of the parties of war.

Vattel following Wolff's dualism, connected jus ad pacem to the development of positivism in the science of

${ }^{96}$ Ibid., ch. 20-XV, p. 810.

${ }^{97}$ Ibid., ch. 20-XVII, p. 811.

${ }^{98}$ Ibid.

${ }^{99}$ Ibid., ch. 25-III, p. 861.

100 Wolff, C. (1764/1934). Jus Gentium Methodo Scientifica Pertractatum (J. H. Drake, Trans.). Washington, D.C.: the Carnegie Endowment for International Peace. paras. 788, 821, pp. 407-408, 425.

${ }^{101}$ Ibid., paras. 789, 822, pp. 408, 425.

102 Ibid., para. 888, pp. 454-455.

${ }^{103}$ Ibid., para. 986, p. 500.

104 Ibid., para. 989, p. 502.

105 Ibid., para. 990, p. 502.

${ }^{106}$ Ibid., para. 993, p. 504. 
international law. He differentiated the law of nations into two systems: the natural or necessary law of nations and the positive law of nations; furthermore, he classified the positive law of nations into three divisions: the voluntary law of nations, the conventional law of nations, and the customary law of nations. ${ }^{107}$ Then, Vattel positioned the traditional just war doctrine as a theory falling within the domain of the natural law of nations; while he considered formal or regular war, where both belligerents could be just, ${ }^{108}$ in the voluntary law of nations. According to this taxonomy of war concepts, Vattel advanced the dualism of jus post bellum in the identical fashion as Wolff: jus victoriae based on a discriminate concept of peace in the natural law of nations, and jus ad pacem based on an indiscriminate concept of peace in the voluntary law of nations.

On jus victoriae, Vattel explained, as with other international lawyers, that a prince who carried on an unjust war should indemnify the just side for the harm done and the losses he had caused, and that the one who had done wrongs should be bound to submit to punishment. ${ }^{109}$ In addition, in a peace treaty where one of the belligerents recognized himself as in the wrong and confessed the injustice of his cause, jus victoriae should be applied. Vattel contended not only that the author of the unjust war should indemnify the just side for the cost of the war, repair the damage occasioned by him, and be subjected to a penalty proportionate to the injuries, but also that even the sovereign whose cause was just should not be absolved of responsibility if he had exceeded the limits of justifiable self-defense. ${ }^{110}$ Vattel explicitly adopted the dualism of jus victoriae and jus ad pacem according to the demarcation between a discriminate concept of peace and an indiscriminate one, not between surrender and peace treaties.

Under the voluntary law of nations, jus ad pacem considered the basic assumption that both belligerents waged regular war, which was accounted as just on both sides regarding its effect. ${ }^{11}$ Thus, when a peace treaty was concluded by political compromise, the original grounds of the war would be left unsettled and neither of the belligerents would be condemned as unjust. ${ }^{12}$ As a consequence, amnesty was the common practice in peace treaties of the day. ${ }^{113}$ In this connection, Vattel illustrated that, even if a peace treaty made no mention of it, amnesty was necessarily included in the treaty from the very nature of the agreement among parties of the war. ${ }^{114}$ Amnesty was interpreted to imply that all claims, including civil as well as criminal for illegitimacy during and because of the war, were extinguished. ${ }^{115}$ These legal effects of amnesty embodied both principles of no punishment and no reparation in jus ad pacem.

Wolff and Vattel, who advocated the dualistic view of jus post bellum according to the classification of the law of nations, acknowledge that a peace treaty between sovereigns was almost always a political compromise, not an act of justice, in the realities of their age. ${ }^{116}$ Accordingly, the important point to note is their succession of great achievements from their focused attention on jus ad pacem that included the principles of no punishment and no reparation, and the significant contributions they made to the development of it. The succession to Wolff's jus post bellum and the further advancement of his tenet by Vattel offered a convenient platform for later international lawyers to develop a positivist's concept of peace that was devoid of all concerns of justice, namely jus ad pacem. ${ }^{117}$

\footnotetext{
107 Vattel, E. (1758/1916). Le Droit des Gens, ou Principes de la Loi Naturelle, appliqués à la Conduite et aux Affaires des Nations et des Souverains (C. G. Fenwick, Trans.). Washington, D.C.: the Carnegie Endowment for International Peace. Intro, para. 27, p. 9.

108 Vattel, E. (1758/1916). Le Droit des Gens, ou Principes de la Loi Naturelle, appliqués à la Conduite et aux Affaires des Nations et des Souverains (vol. 3) (C. G. Fenwick, Trans.). Washington, D.C.: the Carnegie Endowment for International Peace. ch. 12, para. 190 , p. 305.

109 Ibid., ch. 11, para. 185, p. 302.

110 Vattel, E. (1758/1916). Le Droit des Gens, ou Principes de la Loi Naturelle, appliqués à la Conduite et aux Affaires des Nations et des Souverains (vol. 4) (C. G. Fenwick, Trans.). Washington, D.C.: the Carnegie Endowment for International Peace. ch. 2, para. 18 , p. 350.

111 Lesaffer, R. (2011). A Schoolmaster Abolishing Homework? Vattel on Peacemaking and Peace Treaties. In V. Chetail, \& P. Haggenmacher (Eds.), Vattel's International Law in a XXIst Century Perspective (pp. 353-384). Leiden: Martinus Nijhoff Publishers. pp. 364-365. See also, Vattel, supra note 108, ch. 12, para. 190, p. 305.

${ }^{112}$ Vattel, supra note 110, ch. 2, para. 18, p. 350

113 Ibid., ch. 2, para. 20, p. 351.

114 Ibid.

${ }^{115}$ Lesaffer, supra note 111, p. 373. See also, Vattel, supra note 110, ch. 2, para. 21, p. 351.

${ }^{116}$ Lesaffer, supra note 111, p. 359.

117 Ibid., p. 384. Additionally, the doctrine of peace treaties was largely laid out by Wolff and Vattel; accordingly, relatively little was added
} 


\subsection{Positivism - Jus Ad Pacem}

Corresponding straightforwardly to the development of exploration into jus ad pacem by dualists and to the decline of natural law doctrine as a consequence of the pervasion of scientific as well as positivistic methodology in international jurisprudence in the nineteenth century, international lawyers, with regard to jus post bellum, concentrated their attention on the analyses of jus ad pacem as generalized from the common legal effects of peace treaties.

For example, similar to Wolff and Vattel, Oppenheim considered amnesty to be one of the effects of every peace treaty, that is, immunity for all wrongful acts done by belligerents themselves, the members of their forces, and their subjects during war; and yet, it was usual to insert an amnesty clause in a treaty of peace. ${ }^{118}$ He regarded the legal effects of amnesty to include the principle of no punishment, where all so-called war crimes which had not been punished before the conclusion of peace could no longer be punished, and individuals who had committed such war crimes and were arrested for them should be liberated; ${ }^{119}$ and the principle of no reparation where claims for reparation of damages caused by delinquency committed through violation of the rules of legitimate warfare could not be raised after the conclusion of peace unless the contrary was expressly stipulated. ${ }^{120}$

Phillipson, who was a barrister-at-law of the Inner Temple and achieved an empirical study, specialized in peace treaties, noted that amnesty came to be regarded as an essential incident of the declaration of international peace, so that amnesty was necessarily implied in a treaty if it was not expressly embodied in it or otherwise proclaimed. ${ }^{121}$ Phillipson defined the legal effect of amnesty as immunity or exemption from prosecution conferred on belligerents, the members of their armed forces, and their subjects in general, for all wrongful acts committed by them from political motives. ${ }^{122}$ Given that no criminal prosecution against belligerent states was conceivable this legal effect represented the principle of no reparation, as well as that of no punishment. Furthermore, unlike Oppenheim, Phillipson claimed that an amnesty clause could be so comprehensive as to cover all acts including war crimes; ${ }^{123}$ and then, in case an amnesty clause was intended to forgive all violations of the laws of war, not only all persons who had been detained for them and not yet convicted should be released, but also those who had already been tried and imprisoned should be liberated. ${ }^{124}$

These exemplifications of research findings by several positivists regarding jus ad pacem have succeeded in adequately inducing its legal effects from the real practices of peace treaties after the Peace of Westphalia. ${ }^{125}$ However, jus ad pacem, as understood by positivists, was not applied to the Versailles Peace Treaty. In the Versailles Peace Treaty, as a consequence of the conversion from a positivist's concept of war (no discrimination

during the nineteenth century. See, Lesaffer, supra note 30, p. 79.

118 Oppenheim, L. (1906). International Law: A Treatise (vol. 2). London: Longmans. p. 287, para. 274.

${ }^{119}$ Ibid. Unlike other positivists, Oppenheim claimed that amnesty applied to such individuals only as had not yet been convicted, so that those who were undergoing a term of imprisonment need not be liberated at the conclusion of peace. See, Ibid., pp. 287-288, n. 2.

${ }^{120}$ Ibid., pp. 287-288, para. 274. In his second edition, Oppenheim suggested the possibility that this principle of no reparation would be changed in accordance with article 3 of the Convention relative to the Laws and Customs of War on Land. See, Oppenheim, L. (1912). International Law: A Treatise (vol. 2) (2nd ed.). London: Longmans. p. 335, para. 274. However, it should be noted that this convention derived the obligation of all participants in war to make reparation from the analogy of a domestic system of tort law, not from the context of a concept of just peace, or a discriminate concept of peace, which imposes responsibility to one side. See, Division of International Law of the Carnegie Endowment for International Peace. (1921). The Proceedings of the Hague Peace Conferences: The Conference of 1907 (vol. 3). New York, NY: OUP. pp. 26, 139-143.

${ }^{121}$ Phillipson, C. (1916). Termination of War and Treaties of Peace. New York, NY: E. P. Dutton \& Company. pp. $243,244$.

122 Ibid., p. 244.

123 Ibid., p. 247.

${ }^{124}$ Ibid., p. 248. However, Phillipson's definition of amnesty as immunity from punishment granted to all war criminals including the convicted was more in agreement with the very meaning of the term "amnesty" in international law than Oppenheim's definition mentioned earlier. See, Seibert-Fohr, A. (2012). Amnesties. In K. Kaiser et al. (Eds.), The Max Planck Encyclopedia of Public International Law (vol. 1, pp. 358-365). New York, NY: OUP. p. 359. See also, UNCHR. (1993). Progress Report on the Question of the Impunity of Perpetrators of Human Rights Violations, Prepared by Mr. Guissé and Mr. Joinet, pursuant to Sub-Commission Resolution 1992/23. (UN Doc E/CN.4/Sub.2/1993/6). p. 12, para. 38 .

${ }^{125}$ See, Duchhardt, supra note 32, p. 49; Steiger, supra note 29, p. 84; Lesaffer, supra note 30, p. 89. 
between belligerents whether causes were just) to the special concept of war (clear discrimination between the allied powers and the central powers), an indiscriminate concept of peace, that is, a positivist's concept of peace was jettisoned and harsh peace, which is a novel concept of peace bearing a close resemblance to the concept of just peace in classical just war theory, was adopted instead. Soft peace, which intends peace treaties to have lenient legal effects toward vanquished states, had a profound correlation with jus ad pacem in positivism, for the United States attached special importance to international law derived from legal positivism according to a legalistic-moralistic approach conveyed soft peace as the conflicting concept to harsh peace in the preliminaries to the Versailles Peace Treaty. In this view, legal effects of jus ad pacem can function as a bench mark to measure softness of soft peace. An analysis of the birth of the pair of concepts through the process of drafting this treaty is discussed in the next chapter.

\section{Harsh Peace vs. Soft Peace}

\subsection{Tug-of-War for Reparation}

This chapter analyzes reparation and punishment through the Versailles Peace Treaty drafting process, what sort of peace concept respective nations depended upon, and what legal effects they claimed should be provided. These analyses verify that in the preliminaries to the Versailles Peace Treaty, a dichotomous conflict emerged between harsh peace and soft peace. Ultimately, harsh peace won out.

At the beginning of the process, the United States adopted soft peace with regard to reparation. On January 8, 1918, President Thomas Woodrow Wilson, of the United States, advanced 14 principles for peace. In the seventh principle, the necessity of the restoration of Belgium was stressed and it was purported that without this restoration, not only confidence among the nations in international law would be impaired, but also would the whole structure and validity of international law. ${ }^{126}$ According to these dictions, this principle revealed that Wilson realized the recovery after the First World War to be the restoration of the system of international law and its effectiveness. Wilson's methodology attached special importance to securing the overall coherence of international law as a reflection of the foreign policy of the United States, a legalistic-moralistic approach, which "is the belief that it should be possible to suppress the chaotic and dangerous aspirations of governments in the international field by the acceptance of some system of legal rules and restraints." 127

On February 11, 1918, Wilson's position was "no annexations, no contributions, no punitive damages" for post-war peace settlement. ${ }^{128}$ In addition, on October 29, the illustration of Wilson's 14-point principles was propounded. The seventh principle that addressed the restoration of Belgium providing reparations for all illegitimate consequences, which were ascribed to illegitimate act of invasion, including Belgium's war costs, deemed such action as "the healing act" of which Wilson spoke. ${ }^{129}$ In view of this definition of the restoration, namely reparations for the consequences of unlawful actions, the "restoration" in the 14-point principles of January 8 , was a mere translation of executing the traditional state responsibility which imposed reparation for violations of international law. Thus, a clear line should be drawn between restoration in this sense and reparation imposed from the perspective of responsibility for waging a war, which is based not on positivism but on jus victoriae. In other words, the United States advanced the principle of no reparation for war and implied that contributions or punitive damages as responsibility for waging the war would not be exacted in conformity with the formula of February 11. This United States perspective was in close affinity to a positivist's concept of peace adopting the principle of no reparation for waging a war, and taking a lenient attitude toward belligerents; therefore exhibited the softness of soft peace.

However, the spark that would trigger the dichotomous conflict between harsh peace and soft peace could be

\footnotetext{
${ }^{126}$ Address of the President of the United States Delivered at a Joint Session of the Two Houses of Congress, January 8, 1918. In United States Department of State. (Ed.), [1918] Foreign Relations of the United States (hereafter FRUS). (vol. 1). Washington D.C.: U.S. Government Printing Office. p. 15.

${ }^{127}$ Kennan, G. F. (2012). American Diplomacy (sixtieth-anniversary expanded ed.). Chicago: The University of Chicago Press. p. 102. With respect to Wilson's legalistic-moralistic approach, Allan and Keller state that the liberal notion of peace, as the legalistic approach, envisaged by the liberal idealists such as Wilson is founded on existing international legal norms and the model of the Westphalian peace between states or sovereign entities. See, Allan, P., \& Keller, A. (2006). The Concept of a Just Peace, or Achieving Peace Through Recognition, Renouncement, and Rule. In P. Allan, \& A. Keller (Eds.), What is a Just Peace? (pp. 195-215). New York, NY: OUP. pp. 211-212.

${ }^{128}$ Address of the President of the United States Delivered at a Joint Session of the Two Houses of Congress, February 11, 1918. In [1918] FRUS (vol. 1). p. 110.

129 The Special Representative (House) to the Secretary of State. In [1918] FRUS (vol. 1). p. 409.
} 
observed before the armistice of the First World War of November 11. At the Versailles Conference of November 2, Georges Clemenceau, the Prime Minister of France, articulated his essay to impose responsibility to repair on Germany, stipulating a demand for comprehensive reparations for all damages suffered by France in the cease-fire agreement. ${ }^{130}$ France was not advancing a claim for damages as an implementation of state responsibility based on Germany's breach of a specific treaty with France, for violations of treaties in which Germany acted were, as stated in the report of Commission on the Responsibility of the Authors of the War and on Enforcement of Penalties of March 29, 1919, confined to breaches of the neutral treaties with Belgium of April 19, 1839 and with Luxemburg of May 11, 1867. ${ }^{131}$ Accordingly, there is a strong likelihood that France suggested reparations as responsibility for waging the war.

Regarding this, Burnett noted that there were two distinct theoretical positions on reparation. First, the obligation to repair as "derived from the requirement that reparation was due for damage by actions done contrary to the fairly precise canons of international law." 132 This is undoubtedly an attitude grounded in the aforementioned legalistic-moralistic approach of the United States. Second, the obligation to pay reparation as "founded on the Allied assumption that the whole war had resulted from an enemy act of aggression; that, therefore, all the damage caused by the war, including the military expenses of the Allied governments, was chargeable to the enemy - even if not legally chargeable, yet equitably so." 133 France called this "equitable" liability to repair for the total act of damage "integral reparation." 134 Since the latter position is quite akin to the rigid attitude of jus victoriae, to the extent that only defeated belligerents were discriminately charged with the responsibility for waging a war as well as forced to repair all losses and damages emanated from the war, this tenet of integral reparation should possess the nature of harshness of harsh peace. In addition to France, the United Kingdom and Japan sympathized with this concept of peace with respect to reparation.

Thus, the conflict between the soft peace of the United States and the harsh peace of the other allied powers had already come into bud before the armistice. On November 5, 1918, the allied parties transmitted to Germany the Lansing Note enumerating the conditions of the armistice. This document stated that "compensation will be made by Germany for all damage done to civilian population of Allies and their property by aggression of Germany by land, sea, and from the air." 135 This abstract expression left room for interpretations of reparation in terms of the two different positions mentioned herein.

The conflict between harsh peace and soft peace became obvious at the conference of the Commission on the Reparation of Damage held from February 13, 1919. The United States had adopted soft peace by virtue of the suggestion that indemnities for war costs to the Allies, except victims of breaches in neutral treaties such as Belgium, should not be allowed and only reparation based on state responsibility could be exacted, so that reparation as responsibility for the war would not be exacted. ${ }^{136}$ However, France emphasized that the allied

\footnotetext{
${ }^{130}$ Jyū ichi gatsu futsuka no verusaiyu kaigi ni oite zai dokoku girishia jin shakuhō, songai baishō tai doku kaigun kyūsen jōken, ro ra ryōkoku yori no doku gun tettai, pōrando dokuritsu tō shomondai ni tsuki tōgi no ken [On deliberation with regard to the questions about the release of the Greeks within Turkey, reparations, armistice conditions against the German navy, the evacuation of German military from Russia and Romania, and the independence of Poland at the Versailles Conference of November 2]. In Ministry of Foreign Affairs of Japan. (Ed.), [1918] Documents on Japanese Foreign Policy (vol. 2). Tokyo: Ministry of Foreign Affairs of Japan. p. 577 (in Japanese). See also, Extract from the Minutes of the Supreme War Council, November 2, 1918. Reprinted in P. M. Burnett. (1940). Reparation at the Paris Peace Conference: From the Standpoint of the American Delegation (vol. 1). New York, NY: Columbia University Press. pp. $399-400$ (in French).

${ }^{131}$ Commission on the Responsibility of the Authors of the War and on Enforcement of Penalties. (1920). AJIL, 14, 95-154, p. 112.

${ }_{132}$ Burnett, P. M. (1940). Reparation at the Paris Peace Conference: From the Standpoint of the American Delegation (vol. 1). New York, NY: Columbia University Press. p. 3.

133 Ibid., p. 4.

134 Ibid.

135 The Secretary of State to the Swiss Minister (Sulzer). In [1918] FRUS (vol. 1). pp. 468-469.

${ }^{136}$ John Foster Dulles, Delegate of the United States, stated that "claims for reparation must not go beyond the limits of the Pre-Armistice Agreement on the one hand, nor of international law on the other." See, Dulles's Speech before the Commission on the Reparation of Damage, February 13, 1919. Reprinted in P. M. Burnett (1940). Reparation at the Paris Peace Conference: From the Standpoint of the American Delegation (vol. 1). New York, NY: Columbia University Press. p. 563. In addition, in terms of international law, he strongly refused to demand any indemnity from the conquered nation. See, Dulles's Speech before the Commission on the Reparation of Damage, February 14, 1919. Reprinted in P. M. Burnett (1940). Reparation at the Paris Peace Conference: From the Standpoint of the American
} 
parties should demand reparation, including their own war costs, not for violating neutral treaties, but for causing the war, with the aim of punishing enemies and ensuring security ${ }^{137}$ as in jus victoriae. ${ }^{138}$ Moreover, the United Kingdom ventured that the "victorious belligerents have the right to impose upon the conquered for reparation for all the costs and expenses that have fallen upon them in consequence of the war." the term "reparation" embraced "indemnity" for war costs, which positivism had strictly differentiated. ${ }^{140}$ Furthermore, Japan maintained that Wilson's 14-point principles could not confine the right to reparation based on justice and equity, and called for the opinions of France and the United Kingdom. ${ }^{141}$ Thus, the allied and associated powers, except the United States, adopted harsh peace and presumed indemnity for war costs to be included in reparation based on the responsibility for waging a war as in jus victoriae. ${ }^{142}$

However, the United States converted its concept of peace to harsh peace, while adopting policies to moderate this harshness. As a result of this change, the allied parties managed to reach a compromise on the matter of reparation. The First Dulles Draft of February 21 provided that Germany should make integral reparation that included compensation for damages as well as indemnity for war costs of all the allied and associated nations. ${ }^{143}$ Since the United States admitted Germany's responsibility to repair the Allies who were not the victims of any violation of a neutral treaty, the United States dismissed soft peace, which could impose upon a defeated nation only reparation grounded on state responsibility. At the same time, this draft stipulated the waiver of claims not

Delegation (vol. 1). New York, NY: Columbia University Press. pp. 570-571. Accordingly, it can be safely stated that the United States, from the perspective of a legalistic-moralistic approach, respected international law, including an agreement with the central powers, and repelled indemnity for war costs, which were confused with reparation as an implementation of state responsibility. What has to be noticed is that, in positivism, an indemnity for war costs was a completely separate notion from reparation for illegitimate acts in war-time. On this point, see, Steiger, supra note 29, pp. 85-87.

${ }^{137}$ Ministry of Foreign Affairs of Japan. (1920). Treaty Explanation: Explanatory Document for Peace Treaties between Allied Nations and Germany. Tokyo: Ministry of Foreign Affairs of Japan. p. 631 (in Japanese). The delegate of France stated that, "The final agreement relative to indemnity is the armistice, which was approved by the same persons as authorized the Allied declaration of Nov. 3. This agreement makes full reservation as to the reparation to be demanded." See, Dulles, J. F. "Analysis of Debate on Principles Governing Reparation," February 24, 1919. Reprinted in P. M. Burnett. (1940). Reparation at the Paris Peace Conference: From the Standpoint of the American Delegation (vol. 1). New York, NY: Columbia University Press. p. 616. Accordingly, for France, indemnity was associated with reparation since responsibility for waging a war could cover all damages and losses from the war.

138 See, e.g., Suárez, supra note 58, ch. 7, paras. 7, 20.

139 Sumner's Speech before the Commission on the Reparation of Damage, February 13, 1919. Reprinted in P. M. Burnett. (1940). Reparation at the Paris Peace Conference: From the Standpoint of the American Delegation (vol. 1). New York, NY: Columbia University Press. p. 569. It also appears to be stated that, "The agreement as to terms of peace embrace[s] not only the 14 points but subsequent addresses of the President, which stipulate that 'each part of the final settlement must be based upon the essential justice of that particular case.' It is just that war costs be borne by the aggressor" and "Germany by violating the Belgian Treaties imposed a duty upon England to go to the defense of Belgium and gave all other powers the right to do so. Germany thus made herself liable for the war costs of the Allied and Associated Powers." See, Dulles, J. F. "Analysis of Debate on Principles Governing Reparation,” February 24, 1919., supra note 137, pp. 615,617 .

140 The theoretical rationale for indemnity against war costs should be based on the resemblance to the costs of a lawsuit filed with a domestic court. See, Lloyd George, D. (1938). The Truth about the Peace Treaties (vol. 1). London: V. Gollancz. pp. 462-463. This justification is identical to that of a positivist's concept of peace, so that, from the perspective of positivism, the United Kingdom explicitly connected two distinct notions.

${ }^{141}$ Ministry of Foreign Affairs of Japan, supra note 137, pp. 631-632.

${ }^{142}$ Italy and Serbia conceived that, "the words 'all damage done' in the note of Nov. 5 include damage resulting indirectly, as well as directly, and among such indirect damage is war costs." See, Dulles, J. F. "Analysis of Debate on Principles Governing Reparation," February 24, 1919., supra note 137, p. 616.

143 "The German Government undertakes to make full and complete reparation, as hereinafter provided, for damage as hereinafter defined, done by the aggression of Germany and/or its allies to the territories and populations of the nations with which the German Government has been at war."; "Certain of the governments at war with Germany, [believing] that it is just and within the contemplation of the principles agreed to as governing the peace settlement, that the German Government shall, in addition to the reparation above specified for, make reparation for the entire cost of the war to the governments with which Germany has been at war and the indirect damage flowing therefrom..." See, First Dulles Draft, February 21, 1919. Reprinted in P. M. Burnett. (1940). Reparation at the Paris Peace Conference: From the Standpoint of the American Delegation (vol. 1). New York, NY: Columbia University Press. p. 604. 
explicitly enumerated, ${ }^{144}$ reflecting the intent of the United States to soften the legal effect of harsh peace.

The March 24 revised draft by the United States, amplified the nature of reparation as responsibility for war by adopting expressions that designated the immediate relatedness between the damage suffered by the Allies and the war caused by the central powers. ${ }^{145}$ In contrast with the First Dulles Draft, this revised version excluded the renouncement of claims and replaced them with mere acknowledgment of the infeasibility of total reparation ${ }^{146}$ with the intention to moderate harsh peace, but with the result that the United States became increasingly committed to harsh peace. In response to the revised draft of March 24, David Lloyd George, the Prime Minister of the United Kingdom, presented a memorandum to the Council of Four on March 29, in which the allied nations retained the right to claim full reparation, while simultaneously acknowledging that it was impracticable for the central powers to make complete reparation as was stated in the March 24 draft of the United States. ${ }^{147}$ Finally, the compromise within the allied powers began to be arranged.

After April 1919, from the deliberations of the Commission on the Reparation of Damage and the Council of Four, the allied governments agreed and affirmed the responsibility of the enemies for causing all the loss as well as damage the Allies had suffered as a consequence of the aggression of the enemies, and demanded reparation for all damage done to the civilian population of the allied powers, and to their property by the invasion. On the other hand, the allied governments recognized the limitedness of the financial resources of the central powers and the impracticability of them making full reparation or eliminating indemnity for the war costs of the allied powers. ${ }^{148}$ Since there was an agreement that excluded indemnity for the war costs of the Allies, these compromises showed a tendency to moderate harsh peace more than was shown in the First Dulles Draft of February 21. However, the price would be paid for this appeasement by requiring compensation from the central nations to the extent of their utmost capacity.

The adoption of harsh peace within the allied nations regarding reparation was determined through allied rebuttals to Germany protests. On May 13, Brockdorff-Rantzau, the German Peace Delegate, contended that by virtue of the Lansing Note, Germany accepted the obligation to make reparation independent of the question of responsibility for the war. ${ }^{149}$ That is to say, Germany adopted the original view of the United States drawing on soft peace as the understanding of the Lansing Note. On May 15, to refute this German protest, the allied and associated powers maintained that it was only possible to conceive of the obligation to make reparation if its origin and cause were the responsibilities of the author of the damage, so that Germany implicitly recognized both the aggression and responsibility, but clearly by consenting to the Lansing Note, which stated that such an obligation arose out of Germany's aggression. ${ }^{150}$ This counterargument unequivocally shows that the Allies, including the United States, deemed the source of German obligation to make reparation as responsibility for the

\footnotetext{
144 "It is [agreed,] however, that the ability of the German Government and nation to make reparation is [limited to such an extent as will render] the making of such complete reparation [impracticable, and] accordingly the governments at war with Germany renounce the right to insist upon reparation other than is expressly specified for herein." See, ibid., p, 604.

145 "The loss and damage to which the Allied and Associated Governments and their nationals have been subjected, as a direct and necessary consequences of the war imposed upon them by the Enemy States, is upwards of [800 thousand million marks.]" See, The Third Revise, March 24, 1919. Reprinted in P. M. Burnett. (1940). Reparation at the Paris Peace Conference: From the Standpoint of the American Delegation (vol. 1). New York, NY: Columbia University Press. p. 704.

146 "[It is recognized by all of the Allied and Associated Governments] that the financial and economic resources of the Enemy States are not unlimited, and that it will therefore be impracticable for the Enemy States to make complete reparation [for the loss and damage, above stated, resulting from the aggression of such Enemy States.]" See, ibid.

147 "Notwithstanding the indisputable claim of the Allied and Associated Governments to full compensation, they recognize that the financial and economic resources of the enemy states are not unlimited and that it will therefore, so far as they can judge, be impracticable for the enemy states to make complete reparation." See, Notes of a Conversation Which Took Place in M. Clemenceau's Room at the French Ministry of War, 14 Rue Dominique, on Saturday, March 30 [29], 1919, at 3 p.m. In [1919] FRUS (vol. 5). pp. 15, 19.

148 See, Exhibit 11, Draft of General Clauses and of Categories of Damage, April 4, 1919. Reprinted in P. M. Burnett. (1940). Reparation at the Paris Peace Conference: From the Standpoint of the American Delegation (vol. 1). New York, NY: Columbia University Press. pp. 817-818; Ministry of Foreign Affairs of Japan, supra note 137, pp. 631-632.

149 The Head of the German Delegation (Brockdorff-Rantzau) to the President of the Peace Conference (Clemenceau). In [1919] FRUS (vol. 5). p. 727.

${ }^{150}$ Reply to Principal German Plenipotentiary, Approved by the Council of the Principal Allied and Associated Powers. In [1919] FRUS (vol. 5). p. 742.
} 
war, thus adopting a harsh peace interpretation of the Lansing Note. On May 24, Germany said afresh in remonstrance that the allied governments had completely misunderstood the sense in which Germany gave their assent to the Lansing Note, and that the righteous reading of the Lansing Note was that it was based on soft peace. ${ }^{151}$ In response, the allied and associated powers presented their terms of harsh peace for purposes of clarification and to eradicate any grounds for misunderstanding, reinforcing that responsibility to make reparation as directly originating from waging the war. ${ }^{152}$

\subsection{Engagement to Punish the Ex-Kaiser and Jus In Bello Wrongdoers}

A series of processes, through which related nations had experienced the emergence of antagonistic dual concepts, the choice of harsh peace, and the regulation of this concept, were observable regarding punishment as well as reparation. Analyses of arguments within the Council of Four and Commission on the Responsibility of the Authors of the War and on Enforcement of Penalties (known as the Commission on Responsibilities) revealed the presence of structure that the United States, from the perspective of soft peace, opposed the establishment of the international court for punishment; whereas, the other Allies urged the performance of such a court in terms of harsh peace.

On November 28, 1918, the Imperial War Cabinet of the United Kingdom unanimously resolved that "the ex-Kaiser should be held personally responsible for his crimes against international law." ${ }^{153}$ This resolution represented a firm intent to accuse the ex-Kaiser of international crimes and suggested that any amnesty for him should be omitted from the peace treaty. On December 2, the conference of the Council of Four was held for the first time since the armistice. At this conference, which was not attended by President Wilson, the French and Italian prime ministers endorsed the attitude adopted by the British Imperial War Cabinet, ${ }^{154}$ for the United Kingdom, France, and Italy had reached an agreement that the ex-Kaiser as well as the wrongdoers of serious offenses against jus in bello should be brought to trial before an international court; accordingly, they requested the United States to come to the same conclusion. ${ }^{155}$ The outcome of this conference was an intent to punish all the culpable, which in principle negated amnesty in the peace treaty for not only the ex-Kaiser but also for those who had committed grave crimes against jus in bello. This decision constituted the adoption of harsh peace since it is quite analogous to jus victoriae, in which punishment is thoroughly inflicted.

However, at the plenary session of the Commission on Responsibilities of March 13, 1919, the United States held to its legalistic-moralistic approach to international law of the time when waging an aggressive war itself was not considered an international crime. Therefore, the United States insisted that there were no juridical measures in international law to punish the authors of the war for the aggression. ${ }^{156}$ Instead of attempting to bring the ex-Kaiser to trial before a court of justice, the United States proposed that the Allies should establish an International Commission of Inquiry "to investigate and to report upon the extent of the responsibility of the ex-Kaiser from the political, legal and moral point of view for the acts of the German authorities, civil and

151 Translation of Note from Herr Brockdorff-Rantzau [to the President of the Peace Conference (Clemenceau)]. In [1919] FRUS (vol. 6). pp. $38-40$.

${ }^{152}$ Reply of the Allied and Associated Powers to the Observations of the German Delegation on the Conditions of Peace. In [1919] FRUS (vol. 6). p. 963.

${ }^{153}$ Lloyd George, supra note 140, p. 114.

154 Ibid.

${ }^{155}$ Mr. D. H. Miller to Colonel E. M. House. In [1919] FRUS (vol. 1). pp. 335-336; The Acting Secretary of State to the Secretary of State. In [1919] FRUS (vol. 1). p. 341. The following telegram was sent to President Wilson on behalf of the prime ministers of the United Kingdom, France, and Italy: “...the three Governments agreed to recommend that a demand ought to be presented to Holland for the surrender of the person of the ex-Kaiser for trial by an international court, to be appointed by the Allies, on the charge of being the criminal mainly responsible for the War and the breaches of international law by the forces of Germany by land, sea, and air...In coming to the conclusion set forth above, the Conference were influenced by the following principal considerations:- (a) That justice requires that the ex-Kaiser and his principal accomplices who designed and caused the war with its malignant purpose, or who were responsible for the incalculable sufferings inflicted upon the human race during the war, should be brought to trial and punished for their crimes..." See, Lloyd George, supra note 140, pp. 143-145.

156 "Restrained by reverence for law which is inseparable from that high sense of justice which is essential to social order, the nations which have suffered so grievously may be unable to mete out through judicial channels retribution to the guilty." See, Resolution Suggested by Mr. Lansing at the Meeting of the Commission of Responsibilities, March 12, 1919. Reprinted in Scott, J. B. (1921). The Trial of the Kaiser. In E. M. House, \& C. Seyour, Litt.D. (Eds.), What Really Happened at Paris. New York, NY: C. Scribner. p. 476. 
military, in violation of the laws and customs of war committed during the course of the war." ${ }^{157}$ Similarly, the United States took a contrary position to the other three powers as it spoke out against an international court for punishment. It is possible to conjecture that the United States contemplated entrusting punishment of those who were guilty of offenses against jus in bello to domestic military tribunals of the respective belligerents as was traditional. Based on a positivist's concept of peace, convictions for violations of jus in bello which were sentenced by domestic military tribunals in a period of occupation would be annulled by an amnesty clause in a peace treaty. ${ }^{158}$ Accordingly, since the views of the United States can be associated with the structure of a positivist's concept of peace, as well as eschewing punishment through trials before an international court, the United States adopted soft peace.

The dichotomy was further disclosed by a report of the Commission on Responsibilities and the reservations to it by the United States and Japan. In the report of March 29, the trial of the ex-Kaiser before an international court was denied, while those who had breached jus in bello were explicitly excluded from any amnesty in the peace treaty and were surrendered to the respective national tribunals of the Allies or to international tribunals. ${ }^{159}$ However, the United States presented a memorandum of reservations to the report on April 4. The American delegation asserted that there were no rules in international law that stated that a violation of the laws and customs of war should be defined as international crime and punished. ${ }^{160}$ Accordingly, they proposed that those who breached the laws and customs of war should be tried before national military tribunals of the respective allied powers. ${ }^{161}$ This suggestion can also be connected with the structure of a positivist's concept of peace as aforementioned. Nevertheless, the United States did not present any reservation about the explicit exclusion of an amnesty clause from the peace treaty. Thus, the United States anticipated sentencing and punishment by domestic military tribunals. Assuming that this was the case, harsh peace could be observed. Note that Japan also presented reservations and raised a question of whether it could be admitted as a principle of international law that an international tribunal could, after the conclusion of a war, try an individual who was presumed to be guilty of a crime against the laws and customs of war. ${ }^{162}$

As a result of the deliberations by the Council of Four, the United States converted to harsh peace and employed measures to mitigate the legal effects based on this concept for punishment as it had for reparation. On April 10, in a memorandum to the delegation of Japan, the United States urged the Japanese government to concur with the institution of international tribunals by which the ex-Kaiser and persons suspected of crimes against jus in bello were tried. ${ }^{163}$ In this memorandum, the United States provided not only that those who violated the laws and customs of war should be brought to trial before a national or international military tribunal as in the March 29 report of the Commission on Responsibilities, but also that the ex-Kaiser would be surrendered for trial before a special international tribunal. ${ }^{164}$ Therefore, in principle, the United States took no account of stipulating

\footnotetext{
${ }^{157}$ Mr. Lansing's Suggestion of Appointment of a Commission of Inquiry as to the Responsibility of the Kaiser. At the Meeting of the Commission of Responsibilities, March 12, 1919. Reprinted in Scott, J.B. (1921). The Trial of the Kaiser. In E. M. House, \& C. Seyour, Litt.D. (Eds.), What Really Happened at Paris. New York, NY: C. Scribner. p. 477.

${ }^{158}$ See, Chapter 2, Section 2.3.

159 "The acts which brought about the war should not be charged against their authors or made the subject of proceedings before a tribunal."; "That the enemy governments shall, notwithstanding that peace may have been declared, recognize the jurisdiction of the national tribunals and the high tribunal, that all enemy persons alleged to have been guilty of offences against the laws and customs of war and the laws of humanity shall be excluded from any amnesty to which the belligerents may agree, and that the governments of such persons shall undertake to surrender them to be tried." See, Commission on the Responsibility of the Authors of the War and on Enforcement of Penalties, supra note 131, pp. 120, 123.

${ }^{160}$ Ibid., p. 146.

161 Ibid.

${ }^{162}$ Ibid., pp. 151-152.

${ }^{163}$ Sensō sekinin mondai (toku ni doku tei shobun mondai) ni taisuru nihon iin no taido ni tsuki beikoku daitōryō no assen [Good offices of the president of the United States on the attitude of the Japanese delegates toward the question of the responsibility for the war (especially the question of proceedings against the Kaiser)]. In Political Affairs Bureau of Ministry of Foreign Affairs of Japan. (Ed.). (1919). Progress Report on Paris Peace Conference of 1919 (vol. 6). Tokyo: Ministry of Foreign Affairs of Japan. pp. 65-66 (in Japanese).

164 "1. All persons guilty of crimes under the law of war to be tried by military tribunals in usual way and sentenced, if convicted, to the usual punishments. In case crime was committed against nationals of only one of belligerents, trial to be by the military tribunals of that belligerent. In case crime was against nationals of several of belligerents, trial to be by military tribunal made up out of personnel of military
} 
an amnesty clause in the peace treaty. However, regarding the trial of the ex-Kaiser, President Wilson stressed the quality of this trial as political by three means. ${ }^{165}$ The first was that the ex-Kaiser should be tried on charges not of "a violation of criminal law" but of "a supreme offence against international morality and the sanctity of treaties." The second was an "offence against international morality" that was designated not as a legal, but as a political offense. The third was that Wilson thought that the punishment should be a political and not a criminal punishment. Extinguishing the nature as a trial of justice by these techniques, the United States succeeded in avoiding an immediate collision between the trial of the ex-Kaiser and international law, which did not define aggressive war as an international crime. This attitude was applied to moderate harsh peace by building on a legalistic-moralistic approach. However, this softening was weakened by Wilson's agreement with Lloyd George on the omission of a phrase which provided that the ex-Kaiser be publicly arraigned not for a criminal offense. ${ }^{166}$

It follows from what has been said that, regarding reparation and punishment, the legalistic-moralistic approach of the United States made it an advocate for soft peace with an adherence to positivism. This approach amplified the incompatibility of soft peace with harsh peace, which had been exemplarily adopted by the United Kingdom and France as they pursued realistic interests in domestic and international fields. Ultimately, they reached a point of compromise that the legal effects of harsh peace should be relaxed. The dualism between soft peace and harsh peace recurred in the drafting process of the Treaty of Peace with Japan. Soft peace was conclusively adopted and adjusted as analyzed in the following chapters.

\section{Re-selection of Harsh Peace}

\subsection{Japan's Apprehension}

From Chapters 4 to 8 , the author analyzes and enters into the process of diplomatic negotiations for the Treaty of Peace with Japan. As a consequence, he demonstrates that the allied powers ultimately adopted soft peace as a strong reaction against the Versailles Peace Treaty and its concept of peace. However, in the initial phases of the process, the harsh peace of the Versailles Peace Treaty exercised a significant influence on the related states as follows.

Prior to the allied nations exhibiting thoughts on the peace treaty explicitly, as a defeated nation, Japan recognized the strong possibility that the alliances would adopt harsh peace in this peace treaty. On October 22, 1945, shortly after surrendering on September 2, Japan determined the amount of reparations for East Asian nations as an important issue to be stipulated in the peace treaty; and made a comparative analysis with the Versailles Peace Treaty. ${ }^{167}$ In this document, by evoking a prediction of responsibility for reparation, Japan recognized that the adoption of harsh peace of the Versailles Peace Treaty would impose reparation upon only a defeated nation in the same manner as jus victoriae.

This supposition of harsh peace was also salient in a document named, "Comparative examinations of a conceivable allied nations' draft of the peace treaty and Japanese requests" of January 26, $1946 .{ }^{168}$ In this

tribunals of belligerents affected. Accused in every case to be entitled to name his own counsel.

2. Request to be made of Holland to deliver Ex-Kaiser into the hands of the Allied and Associated Powers for trial before special tribunal that tribunal to consist of five judges, one of such judges to be appointed by each of the five powers here named; namely United States of America, Great Britain, France, Italy and Japan; the offences for which it is proposed to try him not to be described as a violation of criminal law but as a supreme offence against international morality and the sanctity of treaties. Punishment to be determined upon is left to one tribunal by seizing the highest motives of international policy, with a view to vindicating solemn obligations of international undertakings and the validity of international morality."

See, Outlines Suggested with Regard to Responsibility and Punishment. Reprinted in Political Affairs Bureau of Ministry of Foreign Affairs of Japan. (Ed.) (1919). Progress Report on Paris Peace Conference of 1919 (vol. 6). Tokyo: Ministry of Foreign Affairs of Japan. pp. 66-67.

165 See, Scott, J. B. (1921). The Trial of the Kaiser. In E. M. House, \& C. Seyour, Litt.D. (Eds.), What Really Happened at Paris. New York, NY: C. Scribner. pp. $475,478$.

${ }^{166}$ Notes of a Meeting Held at President Wilson's House in the Place des Etats-Unis, Paris, on Thursday, May 1, 1919, at 11 a. m. In [1919] FRUS (vol. 5). p. 389.

${ }^{167}$ Heiwa jōyaku teiketsu no hōshiki oyobi jiki ni kansuru kōsatsu [Considerations about how and when Japan should conclude a peace treaty]. In Ministry of Foreign Affairs of Japan. (Ed.). (2006). Documents on Japanese Foreign Policy: Treaty of Peace with Japan Preparatory Work. Tokyo: Ministry of Foreign Affairs of Japan. (hereinafter DJFP: Preparatory Work). pp. 5, 7-8 (in Japanese).

${ }^{168}$ For one of the other examples of this supposition was described in the document drafted on February 1, 1946. See, Heiwa jōyaku no naiyō ni kansuru gensoku teki hōshin no kenkyū oyobi rengō koku an to wagahō kibō an to no hikaku kentō ni tsuite [On the study of 
document, Japan stated a wish to avoid "dictated peace" as was adopted in the Versailles Peace Treaty, realized severe responsibility for reparation, and strongly criticized such rigorousness. ${ }^{169}$ In addition, in May, Japan predicted that a blanket provision concerning reparation and clarifying Japan's responsibility for waging the war would be provided in the peace treaty. ${ }^{170}$ A similar recognition was also presented in the following year. ${ }^{171}$

\subsection{Harsh Peace Re-selected by the Two Powers}

The United States, who played a vital role in drafting the Treaty of Peace with Japan, initially adopted harsh peace despite recommending the adoption of soft peace at the end of the First World War. The draft of the peace treaty drawn up by the Division of Northeast Asian Affairs in the Department of State on March 19, 1947 imposed stringent reparation on Japan ${ }^{172}$ and was criticized for its affinities with the Versailles Peace Treaty. ${ }^{173}$

A new draft of August 5, which was a revision of the March draft, followed in general the principles applied to treaties with satellite nations and Austria that were concluded soon after the end of the Second World War. ${ }^{174}$ The United States' concept of peace, as inferred in the August draft, can be considered as harsh peace itself, for these treaties with the satellite nations can be construed as being based on the concept of peace identically applied to the Versailles Peace Treaty. ${ }^{175}$

Another nation that played a major role in drafting the Peace Treaty with Japan was the United Kingdom, which also adopted harsh peace. On January 20, 1947, William MacMahon Ball, the delegate of the British Commonwealth of the Allied Council for Japan, held talks with Koichiro Asakai, the general manager of the Central Liaison Office of Japan. In these talks, MacMahon Ball, presupposing the presence of reparation from Japan, described two conceivable goals for reparation. One was to eliminate the ability of Japan to perform another war; the other was punishment for Japan. MacMahon Ball claimed that he did not have the latter objective and that he supported only the observations of Australia, which reflected the former. ${ }^{176}$ Therefore, British Commonwealth nations did have both of these purposes of claiming reparation in close resemblance to the purposes claimed by France and construed as identical to jus victoriae at the Conference of the Commission on the Reparation of Damage in February 1919. ${ }^{177}$ Accordingly, since claiming reparation from Japan was

principles bearing on contents of the peace treaty, and comparative examination of the allied nations' draft of the peace treaty and proposals of Japanese requests]. In DJFP: Preparatory Work. p. 72 (in Japanese).

${ }^{169}$ Soutei sareru rengō koku gawa heiwa jōyaku an to wagahō kibō to no hikaku kentō [Comparative examinations of a conceivable allied nations' draft of the peace treaty and Japanese requests]. In DJFP: Preparatory Work. pp. 17, 20-21 (in Japanese).

${ }^{170}$ Heiwa jōyaku mondai kenkyū kanji kai ni yoru dai ichiji kenkyū hōkoku [The first research report by the workshop of officers for questions of the peace treaty]. In DJFP: Preparatory Work. p. 101 (in Japanese).

${ }^{171}$ Heiwa jōyaku ni taisuru nihon seifu no ippan teki kenkai (dai ichi kō) [The general observations of the Japanese government about the peace treaty (the first draft)]. In DJFP: Preparatory Work. pp. 182-183 (in Japanese).

172 See, Dunn, F. S. (1963). Peace-Making and the Settlement with Japan. Princeton, NJ: Princeton University Press. pp. 58-59. This draft is not printed in Foreign Relations of the United States. For this point, see, Memorandum by the Political Adviser in Japan (Atcheson) to General of the Army Douglas MacArthur. In [1947] FRUS (vol. 6). p. 452, ns. 75, 76. This directionality of stern reparation was along the lines of the reparation formula advanced in the letter of December 6, 1945, and the report of April 1, 1946 made by Edwin W. Pauley. See, Mr. Edwin W. Pauley, Personal Representative of the President on Reparations, to President Truman. In [1945] FRUS (vol. 6). pp. 1004-1009; Pauley, E. W. (1946). Report on Japanese Reparations to the President of the United States: November 1945 to April 1946. Washington, D.C.: Ambassador of the United States and Personal Representative of the President on Reparations. pp. 1-9.

173 "This was, in general, a Draconian approach which would have perpetuated the bitterness of World War II. To my mind, the draft was unworkable and self-defeating and made the approach to peace retaliatory. It was the Treaty of Versailles all over again, and this indicated that we had learned little from the experiences of the previous twenty-seven years." Sebald, W. J. (1965). With MacArthur in Japan: A Personal History of the Occupation. New York, NY: W.W. Norton. pp. 243-244.

${ }^{174}$ Memorandum by the Chief of the Division of Northeast Asian Affairs (Borton) to the Counselor of the Department (Bohlen). In [1947] FRUS (vol. 6). p. 478.

175 This construction is inferred from structural similarities between peace treaties with satellite nations and the Versailles Peace Treaty. See, Puttkamer, E. (1982). Peace Treaties of 1947. In R. Dolzer, et al. (Eds.), Encyclopedia of Public International Law (vol. 4, pp. 111-118). Amsterdam: North-Holland. p. 119.

${ }^{176}$ Asakai MacMahon Ball kaidan (dai ichi kai) [The talks between Asakai and MacMahon Ball (the first)]. In DJFP: Preparatory Work. pp. 160-161 (in Japanese).

177 See, Chapter 3, Section 3.1. 
regarded as a natural premise and the aims of it could be extrapolated as emanating from jus victoriae, it was inevitable that the British Commonwealth nations, including the United Kingdom, were presumed to hold harsh peace as their rudimentary concept. "[T]he unity of the Commonwealth in favoring a restrictive treaty with Japan"178 was derived from this attitude at the Canberra Conference held from August 26 to September 2, $1947 .^{179}$

\subsection{Japan's Exertion to Elude Harsh Peace}

Japan made every effort to obstruct the drafting of a rigorous peace treaty. In the third draft of the general observations of the Japanese government about the peace treaty on June 5, 1947, Japan contended that the peace treaty should approve and apply the established principles of international law on terminating war. ${ }^{180}$ It is likely that this thesis meant that Japan requested the application of rules and principles empirically induced from different peace treaties, namely the norms derived from the concept of peace as evolved from positive international law and known as soft peace.

The memorandum of the Japanese views, the Ashida Memorandum was received by George Atcheson Jr., the delegate of the United States of the Allied Council for Japan, at the talks between Atcheson and Hitoshi Ashida, the Minister of Foreign Affairs of Japan, on July 26. ${ }^{181}$ This memorandum stated that Japan expected a peace settlement in accordance with the established principles of international law. ${ }^{182}$ But, the Japanese government still indicated that Japan was resolved to meet the reparation requirements at all costs, but desired the allied parties to enable the country to attain a self-supporting economy and maintain reasonable standards of living. ${ }^{183}$

Reflection on these attitudes makes clear that Japan was of two incompatible but intricately intermingled minds. For one, Japan intended to request adopting not harsh peace but soft peace, in which reparations were customarily waived, by requesting the application of established principles of international law. Additionally, Japan presupposed the responsibility for reparation, but sought to relax the application of harsh peace by asking for the acceptance of a self-supporting economy and reasonable standards of living. Keeping these contradictory positions in mind, as the defeated nation that predicated the adoption of harsh peace, Japan intended to achieve a unified directionality to reduce the devastation of the peace treaty as much as possible.

Several observations in this chapter demonstrate that the two leading alliance powers and even the defeated party conceived harsh peace as an underlying concept for drafting the Treaty of Peace with Japan. Therefore, the drafting process began with the selection of the concept of peace yielded by the Versailles Peace Treaty, that is, harsh peace.

\section{Transition to Soft Peace}

\subsection{The United States as a Herald}

\footnotetext{
${ }^{178}$ Dunn, supra note 172, pp. 66-67.

179 E.g., on August 28, the British Commonwealth nations enunciated their yearning to secure Japan's concession to crimes against peace in the Japanese peace treaty. Another example is that the Commonwealth arrived at the conclusion, on August 29, that Japan should pay reparation exactly unless the Japanese nation was enslaved. See, Kyanbera ei renpō shokoku kaigi ni tsuite [On the Canberra Conference of the British Commonwealth]. In DJFP: Preparatory Work. pp. 308, 309 (in Japanese).

${ }^{180}$ Heiwa jōyaku ni taisuru nihon seifu no ippan teki kenkai (dai san kō) [The general observations of the Japanese government about the peace treaty (the third draft)]. In DJFP: Preparatory Work. pp. 201-202 (in Japanese). We should not ignore that there were remarks that Japan should acknowledge responsibility for waging the war and not require the application of established principles of international law. See, "Heiwa jōyaku ni taisuru nihon seifu no ippan teki kenkai" ni taisuru iken chōshu nitsuite [On the hearing opinions on "the general observations of the Japanese government about the peace treaty"]. In DJFP: Preparatory Work. pp. 211-212 (in Japanese).

${ }^{181}$ Ashida Atcheson kaidan [The talks between Ashida and Atcheson]. In DJFP: Preparatory Work. p. 249 (in Japanese). The same document was handed to Major General Courtney Whitney, Chief of the Government Section at General Headquarters of the Supreme Commander for the Allied Powers (GHQ/SCAP), on July 28. See, Ashida Whitney kaidan [The talks between Ashida and Whitney]. In DJFP: Preparatory Work. p. 261 (in Japanese). Atcheson and Whitney returned the memorandum, respectively, on July 28. See, Atcheson oyobi Whitney ni shukō shita Ashida oboegaki no henkyaku ni tsuite [On the return of Ashida Memorandum, which was handed to Atcheson and Whitney]. In DJFP: Preparatory Work. pp. 263-264 (in Japanese). It should also be added that the memorandum was also delivered to MacMahon Ball (the British Commonwealth) on August 11. See, Ashida MacMahon Ball kaidan [The talks between Ashida and MacMahon Ball]. In DJFP: Preparatory Work. pp. 276-277 (in Japanese).

182 Atcheson ni taisuru kaidan an [The draft of memorandum for the talks with Atcheson]. In DJFP: Preparatory Work. p. 245 (in Japanese).

${ }^{183}$ Ibid., p. 247.
} 
The transition to soft peace was pioneered solely with respect to the complication of reparation, by the United States as the leading party. On October 14, 1947, George F. Kennan, the Director of the Policy Planning Staff of the State Department, proposed in his memorandum that: “...Minimum reparations, consistent with existing commitments, should be exacted, and none out of current production..."184 This proposition of minimum reparations without satisfaction from production unequivocally indicated that the United States meant to moderate harsh peace.

The emerging posture of the United States was reflected in the "Japanese Peace Treaty Draft of January 8, 1948." This draft stated that "The United States reparation proposal does not advocate reparation from current production," although the draft provided that Japan should make equitable reparations. ${ }^{185}$ Thus, the easing of harsh peace can be observed here. Nevertheless, the provisions about how war criminals were to be treated followed the pattern already established in the Italian Treaty. ${ }^{186}$ The United States did not consider the amnesty of a positivist's concept of peace, rather electing harsh peace in this case. Accordingly, the relaxation in the responsibility of Japan for reparation meant not the conversion of harsh peace, but its mere moderation.

However, General of the Army Douglas MacArthur, the Supreme Commander for the Allied Powers (SCAP), advocated no reparation in a conversation with George F. Kennan who visited Japan in March $1948 .{ }^{187}$ On March 5, 1948, MacArthur underscored no reparation from Japan in the peace treaty except for portions already fulfilled in the occupational period. ${ }^{188}$ Furthermore, in the conversation between MacArthur, Under Secretary of the Army William H. Draper Jr., and Kennan on March 21, MacArthur exhorted the necessity of entirely abandoning the thought of further reparation and tried to aggressively expand his remark by requiring a written agreement from the other allied nations to the renounce all claims for future Japanese reparation. ${ }^{189}$ From these conversations, it was apparent that MacArthur had a conclusive doctrine for conforming to the norms for peace to the realities of Japan under the occupation. ${ }^{190}$

Additionally, the realism of the United States, as advocated by George F. Kennan, shaped the bridge to soft peace. In his explanatory notes of March 25, being strongly affected by the recommendations of MacArthur, Kennan shifted from his former "unrealistic" view that reparation should come out of Japanese industrial facilities, to the position that no reparation should be demanded. ${ }^{191}$ We can observe here an apparent rebellion against harsh peace and, as the reaction against this concept of peace, the omen of conversion to soft peace to justify the principle of no reparation.

In subsequent actions, the United States constructed the cornerstone for the adoption of soft peace. The "Report by the National Security Council on Recommendations with Respect to United States Policy toward Japan" (NSC13/2) of October 7, showed that the nature of the peace treaty should not be punitive and consequently

\footnotetext{
${ }^{184}$ Memorandum by the Director of the Policy Planning Staff (Kennan). In [1947] FRUS (vol. 6). p. 542.

${ }^{185}$ Analysis of the Japanese Peace Treaty Draft of January 8, 1948. In [1948] FRUS (vol. 6). pp. 659-660.

${ }^{186}$ Ibid., p. 660.
}

${ }^{187}$ It is noteworthy that, in February 1948, Clifford Strike, Chairman of the Overseas Consultant Incorporated, addressed the report on reparation to the Department of the Army of the United States, and recommended against the removal of productive facilities in Japan. See, Overseas Consultants, Inc. (1948). Report on Industrial Reparations Survey of Japan to the United States of America. New York, NY: Overseas Consultants. p. 16.

${ }^{188}$ Conversation Between General of the Army MacArthur and Mr. George F. Kennan, March 5, 1948. In [1948] FRUS (vol. 6). p. 706.

${ }^{189}$ Conversation Between General of the Army MacArthur, Under Secretary of the Army Draper, and Mr. George F. Kennan, March 21, 1948 (Amended March 23, 1948). In [1948] FRUS (vol. 6). p. 711.

${ }^{190}$ The report on the economic position and prospects of Japan advanced by the committee headed by Percy H. Johnston, Chairman of the Chemical Bank and Trust Company, stated that the committee agreed with MacArthur that industrial recovery of Japan on a peaceful basis was necessary to bring about a self-supporting economy. See, Report by the "Johnson ( sic) Committee" to the Secretary of the Army (Royall) on the Economic Position and Prospects of Japan and Korea and Measures Required to Improve Them, Transmitted April 26, 1948. Released to the Press, May 19, 1948. In R. Dennett, \& R. K. Turner (Eds.). (1950). Documents on American Foreign Relations (vol. 10). Boston: World Peace Foundation. p. 162.

${ }^{191}$ Kennan stated, "It is true that we have gone along, up to this time, with all these unrealistic concepts about the removal of Japanese industrial facilities for reparations. In fact, we are probably more responsible than anyone else for the currency which these concepts have gained in the allied community. But there are times and situations when a frank confession of error is the only healthy course." See, Explanatory Notes by Mr. George F. Kennan, March 25, 1948. In [1948] FRUS (vol. 6). pp. 716-717. 
recommended that the United States should try to manipulate several pertinent issues during the occupational period. ${ }^{192}$

To be more specific, it was recommended that all property matters should be immediately resolved in advance of the peace treaty to not hamper the negotiations of this treaty; ${ }^{193}$ the screening of all war crime suspects with a view to releasing those whose cases were not to be prosecuted should be concluded as early as possible; and the trials of other suspects should be instituted and concluded at the earliest possible date. ${ }^{194}$ Thus, this document clearly evidenced the directionality that the United States intended to make the nature of the peace treaty with Japan isolated from being punitive or pitiless, and veered round to leniency.

To this end, the United States sought to established facts by dealing with relevant matters during the occupation to bring about the results that there would be no necessity for severe provisions in the treaty such as imposing obligations about property or war crime trials on Japan. The essay of the United States can be analyzed as the transitional movement toward the adoption of soft peace. As a result of this scheme, on May 12, 1949, Major General McCoy, the representative of the United States in the Far Eastern Commission, made a statement before this commission that "...Japan has already paid substantial reparations through expropriation of its former overseas assets and, in smaller degree, under the advance transfer program. In light of these conclusions, the United States Government is impelled to rescind its interim directive of April 4, 1947, bringing to an end the advance transfer program called for by that directive." 195

The new draft of the Japanese peace treaty of October 13, $1949^{196}$ contained changes of varying degrees of importance in almost all articles ${ }^{197}$ and consequently illustrated that "The underlying concept of the draft was the restoration of sovereignty with as few restrictions as possible"198 though this draft was the revision of the draft of January 8, 1948, which was based on harsh peace. Surely, there remained the obligation of Japan to make reparation; however, the October 13 draft did not refer to the stock of gold in Japan. ${ }^{199}$ Thereby, the reparation from the stock of gold was waived in this draft. ${ }^{200}$ Hence, the United States succeeded in limiting how reparations were made by according great importance to realism. ${ }^{201}$ Thus, the cornerstone for adopting soft peace was being steadily formed, although the principle of no reparation was not achieved.

\subsection{The United Kingdom as a Pursuer}

The United Kingdom followed the road to soft peace, which had already been paved since March 1948 by the United States. On May 27, 1948, Maberley Esler Dening, Assistant to the Under Secretary for Foreign Affairs of the British Foreign Office, and Kennan, the Director of Policy Planning Staff of the United States, held conversations in Washington. Dening, understanding that the United States was in transition to soft peace built on realism, ${ }^{202}$ concluded that '[I]f acquainted with the so-called 'realities of the situation,' the British Cabinet

\footnotetext{
192 "It should be our aim to have the treaty, when finally negotiated, as brief, as general, and as nonpunitive as possible. To this end we should try to clear away during this intervening period as many as possible of the matters which might otherwise be expected to enter into the treaty of peace. Our aim should be to reduce as far as possible the number of questions to be treated in the peace treaty. This applies particularly to such matters as property rights, restitution, etc. Our policy for the coming period should be shaped specifically with this in mind." See, Note by the NSC Executive Secretary (Souers) to President Truman. In [1948] FRUS (vol. 6). p. 858.

${ }^{193}$ However, recommendations on Japanese reparation were separately submitted. See, ibid., p. 862.

${ }^{194}$ Ibid., pp. 861, 862.

195 Extract from a Statement by General McCoy on the United States Government's Decision to End the Interim Programme of Reparation Deliveries, Made before the Far Eastern Commission, 12 May 1949. In M. Carlyle. (Ed.). (1952). [1947-1948] Documents on International Affairs. London: OUP. pp. 728-729.

196 This draft is not printed in Foreign Relations of the United States. See, Memorandum by Mr. Robert A. Fearey, of the Office of Northeast Asian Affairs, to the Deputy Director of the Office (Allison). In [1949] FRUS (vol. 7). p. 877, n. 1.

${ }^{197}$ Ibid., p. 878.

198 Dunn, supra note 172, pp. 83-84. Dunn also stated that "It should be noted that the conception and many of the crucial details of the October 13, 1949, draft were very similar to the treaty finally negotiated by Dulles and signed at San Francisco in 1951.” See, ibid., p. 85.

199 Ibid., p. 84.

200 Ibid.

201 Dunn described that "It should also be noted at this point that the October 1949 draft was thoroughly realistic." See, ibid., p. 86.

202 "Mr. Kennan argued, there is a wide gap between prevalent theories and the realities of the situation. He pointed out that reparations from
} 
might well change its views on the reparations-level of industry problem."203 This conversation provided the United Kingdom with an opportunity to reconsider its concept of peace.

Consequently, the United Kingdom submitted proposals, which attempted to weaken oppressive restrictions on Japan, with the result that the British Commonwealth nations, except Australia and New Zealand, began to be inclined toward the mitigation of harsh peace at the London Conference of the Commonwealth Working Party on the Japanese Peace Treaty from May 1 to $17,1950 .{ }^{204}$ Furthermore, the Commonwealth governments reached the general agreement that reparation should not be taken from Japanese internal industrial assets or current production. $^{205}$

\subsection{Japan as an Onlooker}

In light of the fact that the two leading powers were on their way to soft peace, Japan, the other party to the peace treaty, anticipated that there would be no reparation in the peace treaty. In the document named, "On the economic significances of the peace treaty with Japan" dated May 31, 1950, Japan described two possible intents of the major alliances for reparation: first, to provide the defeated with an economic foundation for constructing a democratic peace-loving nation, and second, political considerations or punishment; then analyzed the first. ${ }^{206}$ Additionally, Japan did not want reparation to be exacted beyond facilities that had already been removed, even though Japan acknowledged responsibility for reparation as the outcome of the defeat. ${ }^{207}$

\section{Soft Peace vs. Soft Peace}

\subsection{Dulles and the 7-point Memorandum}

The entrance to the process by Ambassador John Foster Dulles triggered the abandonment of harsh peace and the adoption of soft peace as a strong reaction against the Versailles Peace Treaty. ${ }^{208}$ Dulles was appointed as the consultant to the Secretary of State and special representative of the president of the United States, and he inherited the lines of Kennan's realism ${ }^{209}$ by being motivated by the actuality of Japan. ${ }^{210}$ At the outset, in a memorandum of June 6,1950, Dulles advanced the principle of no reparation to provide full opportunity for peaceful economic development in Japan. ${ }^{211}$ On September 11, reflecting Dulles' memorandum, the Department of State prepared a "Draft of a Peace Treaty with Japan" and the memorandum for negotiating with other allied nations known as the 7-point Memorandum, in which seven principles for the Japanese peace treaty were described. In this 7-point Memorandum, waiving reparation claims of the allied powers except the disposition of Japanese property in the territories of alliances and the restitution of the allied property was enumerated as one of the seven principles. ${ }^{212}$

Japan's obsolescent industries would be uneconomical and perhaps of no real benefit to recipient countries..." See, Memorandum of Conversation, by Mr. Marshall Green of the Division of Northeast Asian Affairs. In [1948] FRUS (vol. 6). p. 792.

203 Ibid.

${ }^{204}$ Commonwealth Working Party on Japanese Peace Treaty, 1st May to 17th May, 1950, Report (FO371/83830, the United Kingdom National Archives). pp. 1-2.

${ }^{205}$ Ibid., p. 8. However, it should not be overlooked that most delegates of the Commonwealth agreed that Japanese gold should be made available as reparations. See, ibid.

206 Tainichi heiwa jōyaku no keizai teki igi ni tsuite [On the economic significances of the Treaty of Peace with Japan]. In DJFP: Preparatory Work. p. 493 (in Japanese).

${ }^{207}$ Ibid., pp. 493-494.

${ }^{208}$ One of Dulles' deepest convictions regarding the preservation of peace was that the imposition of harsh terms on a defeated enemy would necessarily inspire in him a desire for vengeance and make him want to be militarily powerful again, so that justice, fair play, magnanimity, and humanity were the essential ingredients for peace. The historical basis for Dulles' conceptions was the Versailles Peace Treaty, which he had participated in drafting as one of the delegates of the United States. See, Dunn, supra note 172, pp. 98-99.

209 The line of planning initially supported by Kennan and the Policy Planning Staff was considered to be extremely congenial to Dulles. See, ibid., p. 98.

${ }^{210}$ Dulles enunciated his motive in the explanation to J. Barrington, Ambassador of Burma to the United States on October 19, 1950. See, Memorandum of Conversation, by Colonel Stanton Babcock of the Department of Defense. In [1950] FRUS (vol. 6). p. 1325, n. 2.

${ }^{211}$ Memorandum by the Consultant to the Secretary (Dulles) to the Secretary of State. In [1950] FRUS (vol. 6). p. 1210.

212 "6. Claims. All Parties would waive claims arising out of war acts prior to September 2, 1945, except that (a) the Allied Powers would, in general, hold Japanese property within their territory and $(b)$ Japan would restore allied property or, if not restorable intact, provide yen to 
Rules with identical effect were provided in the "Draft of a Peace Treaty with Japan." 213 Given that Dulles' memorandum of June 6 underlined the principle of no reparation; these rules for waiving claims paraphrased this principle. Furthermore, the draft of September 11 did not contain any clause that indicated the responsibility for waging the war in the same way as the Versailles Peace Treaty. ${ }^{214}$ In addition, the draft restrictively adopted amnesty with legal effect peculiar to a positivist's concept of peace, by providing an affirmative sentence for the power to grant pardon ${ }^{215}$ or clemency to war criminals to be owned and jointly exercised by Japan and relevant allied parties. ${ }^{216}$ All this amounts to saying that the United States defected from the conceptual structure of the Versailles Peace Treaty and hailed that of peace treaties in positivism.

On September 22, Dulles held a conference with Dening, Assistant to the Under Secretary for Foreign Affairs of the British Foreign Office. In this conference, Dulles pioneered a truly liberal treaty of soft peace and gave the United Kingdom the 7-point Memorandum of September 11. ${ }^{217}$ The reactions of the United Kingdom appeared to have been the most favorable and closely aligned with the United States' views in general. ${ }^{218}$

compensate for an agreed percentage of lost value.” Unsigned Memorandum Prepared in the Department of State. In [1950] FRUS (vol. 6). p. 1297.

213 "18. Except as in this Treaty otherwise provided, the Allied and Associated Powers and Japan reciprocally waive claims against each other for acts taken during the state of war hereby ended, prior to September 2, 1945. Japan declares its readiness to enter into similar reciprocal undertakings with nations which broke off diplomatic relations with Japan."; "20. Each of the Allied and Associated Powers will have the right to retain and dispose of all Japanese property, rights and interests within its territory at any time between December 7, 1941, and the coming into force of the present treaty...”; “21. (a) Japan will restore, upon demand, within six months from the effective date of this treaty, the property, tangible and intangible, and all rights or interests of any kind in property, in Japan of the Allied and Associated Powers and their nationals...” Draft of a Peace Treaty With Japan. In [1950] FRUS (vol. 6). pp. 1300-1301.

${ }^{214}$ See, especially, the preamble of this draft. Ibid., p. 1297.

215 In the United States, the legal term "pardon" means remitting the punishment of an individual who has been convicted. On the other hand, "amnesty" in the United States means granting forgiveness for past offenses to certain classes of persons who are subject to trial, but have not yet been convicted. On these points, see, Weisman, N. (1972). A History and Discussion of Amnesty. Co HRLR, 4, 529-540. pp. 529-530. However, as mentioned above, "amnesty" in a peace treaty normally has the legal effect to remit and release war criminals whether they have been convicted. Thus, for the United States, the legal effect of "amnesty" in a peace treaty embraces both "pardon" and "amnesty." Since the United States considered that another trial for war crimes was tacitly prohibited, as will be argued later on, for the United States, the intentional choice of the term "pardon" was inferred, as it could express remitting the punishment of the convicted as one of the legal effects of amnesty in a peace treaty. As will be observed later, in contrast, the United Kingdom, clearly regarded "pardon" as a term whose effect was to invalidate convictions and release the convicted. Accordingly, the legal effect of "pardon" in the United Kingdom was identified with that part of "amnesty" in the peace treaty.

216 " 16 . The power to grant clemency, reduce sentences, parole and pardon with respect to the sentences imposed by military tribunals of the Allied and Associated Powers on persons who are incarcerated in Japan may be exercised jointly by Japan and the Government or Governments which imposed the sentence in each instance. In the case of the persons sentenced by the International Military Tribunal for the Far East, such power may be exercised jointly by Japan and a majority of the Governments represented on the Tribunal." Draft of a Peace Treaty With Japan, supra note 213, pp. 1299-1300.

${ }^{217}$ Dulles "talked at some length on our desire for a truly liberal treaty that would restore Japan fully to the family of nations, contain no political, economic, or military restrictive clauses and give the Japan every encouragement to adhere to the free world and remain opposed to the Communist bloc." Memorandum of Conference, by Colonel Stanton Babcock of the Department of Defense. In [1950] FRUS (vol. 6). p. 1307.

${ }^{218}$ Ibid., p. 1307, n. 2. The reactions of other allied nations to the 7-point Memorandum were as follows. Joseph M. Dodge, Foreign Minister of New Zealand, entertained considerable sympathy for the United States' viewpoint (Memorandum of Conversation, by Colonel Stanton Babcock of the Department of Defense. In [1950] FRUS (vol. 6). p. 1322). Vijaya Lakshmi Pandit, Ambassador of India, expressed agreement with the United States memorandum, except in matters of security, territory, and participants in drafting the peace treaty and presented "India's Preliminary Views on U.S. Memorandum on Japanese Peace Treaty,” which stated “...India has voluntarily renounced any claim for reparations from Japan's internal industrial facilities, she will be in a position to go along with the U.S. proposals." (Memorandum of Conversation, by the Director of the Office of Northeast Asian Affairs (Allison). In [1950] FRUS (vol. 6). pp. 1379, 1383). Percy Claude Spender, Minister of External Affairs and External Territories of Australia, contended that it would be politically impossible for any Australian government to enter into a liberal Japanese peace treaty without firm guarantees against Japanese aggression (Memorandum of Conference, by Colonel Stanton Babcock of the Department of Defense. In [1950] FRUS (vol. 6). p. 1308). Carlos P. Romulo, Foreign Minister of the Philippines and Chief of the Philippine Delegation to the United Nations, emphasized that the United States should give due consideration to the reasonable claims of other states about reparation; but acknowledged that a restrictive treaty would have the 


\subsection{Japan's Encounter with Soft Peace}

Japan, on realizing the United States had adopted soft peace, appreciated the legal effects of a peace treaty based on this concept of peace. In a "Conceivable outline of the Treaty of Peace with Japan" of September 1950, the Japanese government still predicted that there would be provisions for the responsibility for waging the war, the maintenance of measures for war criminals, and reparations from production. ${ }^{219}$ Clearly, Japan had been apprehensive that harsh peace would be applied. However, on October 2, Japan reacted to the United States' adoption of soft peace by drafting the document named, "Framework of the draft of Japanese peace treaty by the United States." ${ }^{220}$ In this document, Japan observed that the United States had put forth a liberal treaty, which did not provide excessive reparation and diverged fundamentally from peace treaties drafted with the exclusive intent to restrain the defeated. ${ }^{221}$

On October 4, Japan immediately drew up drafts of two documents asking the United States to provide legal effects common to peace treaties in positivism, as the effects would be based on soft peace, and thus would apply to Japan. To be concrete, Japan appealed for pulling the plug on another trial and granting a general amnesty in the peace treaty as one of the legal effects of positivism; and for exacting no reparation, especially from production, beyond the facilities already removed, again reflecting the principle of no reparation in positivism. ${ }^{222}$

However, in conversations with the relevant officers of North East Asian Affairs of the Department of State on October 14, the request of Japan for general amnesty for war crimes was repelled, probably because it conflicted with the provision on war criminals in the September 11 "Draft of a Peace Treaty with Japan."223 On the other hand, it was suggested that no reparation would be exacted except for the disposition of Japanese property within the territories of allied parties. ${ }^{224}$

Consequently, Japan reconfirmed the fixed intent of the United Nations to exact no reparation as an illustration of the principle for reparation in the 7-point Memorandum as understood by the Japanese government before the publication, such that the scope of the right to claim reparation was confined to Japanese property already seized by the allied nations in their territories during the war, so that all allied nations waived any further claims on facilities or production. ${ }^{225}$

\subsection{Soft Peace Adopted by the United Kingdom}

The United Kingdom, strongly influenced by the astonishing conversion of the United States, also adopted soft

disadvantage of producing in Japan a body of opinion, which would have as its primary aim the eradication of those restrictive provisions (Memorandum of Conversation, by Colonel Stanton Babcock of the Department of Defense. In [1950] FRUS (vol. 6). pp. 1309, 1311). Burma and the Republic of China raised objections against waiving claims for reparation (Memorandum of Conversation, by Colonel Stanton Babcock of the Department of Defense, supra note 210, p. 1325, n. 2).

219 Tainichi heiwa jōyaku sōtei taikō [Conceivable outline of the Treaty of Peace with Japan]. In DJFP: Preparatory Work. pp. 520, 523, 525-526 (in Japanese).

${ }^{220}$ Note that Japan accurately grasped the change in the concept of peace in the United States at the juncture of publishing the 7-point Memorandum on November 24, 1950. See, Tainichi kōwa nana gensoku [Seven points proposal on Japanese Peace Treaty made by U.S.]. In Ministry of Foreign Affairs of Japan. (Ed.). (2007)., Documents on Japanese Foreign Policy: Treaty of Peace with Japan Negotiation with the United States. Tokyo: Ministry of Foreign Affairs of Japan (hereinafter DJFP: Negotiation with the US). pp. $94-98$ (in English and Japanese).

${ }^{221}$ Beikoku no tainichi heiwa jōyaku an no kōsō [Framework of the draft of Japanese peace treaty by the United States]. In DJFP: Negotiation with the US. pp. 13, 15 (in Japanese).

${ }^{222}$ Beikoku no tainichi heiwa jōyaku an no kōsō ni taiō suru wagahō yōbō hōshin (an) [Draft of policies on Japanese requests corresponding to the framework of the draft of the Japanese peace treaty by the United States]. In DJFP: Negotiation with the US. pp. 20,21 (in Japanese); Taibei chinjyutsu sho (an) [Draft of the document of statement to the United States]. In DJFP: Negotiation with the US. pp. 31, 33 (in Japanese). In the meantime, Japan forwarded its analysis of the international situation, with the result that it deliberated the strong probability of adopting the principle of no reparation as intended by the United States. See, Kokusai jōsei ni tsuite no ichi kōsatsu [A consideration with regard to an international situation]. In DJFP: Negotiation with the US. pp. $54-55$ (in Japanese).

${ }^{223}$ Kōwa mondai ni kansuru bei kokumushō kakarikan no danwa ni tsuite [On conversations with the relevant officers of the Department of State with a bearing on the matters of peace]. In DJFP: Negotiation with the US. p. 63 (in Japanese).

224 Ibid., p. 62.

${ }^{225}$ Beikoku no tainichi kōwa nana gensoku ni tsuite [On the seven points proposal on Japanese Peace Treaty drafted by the United States]. In DJFP: Negotiation with the US. pp. 77-78 (in Japanese). 
peace as its concept of peace. ${ }^{226}$ However, the soft peace of the United Kingdom was distinct from that of the United States as it retained some tenets of harsh peace resulting in an antagonism between the United Kingdom soft peace and the United States soft peace over the legal effects of the peace treaty.

On December 19, 1950, the United Kingdom expressed its severe attitude toward the future of Japan in the document named, "Japanese Peace Treaty: General." While raising superficial objectives grounded in soft peace, ${ }^{227}$ the United Kingdom recommended that first, the responsibility of Japan for waging the war should be mentioned; ${ }^{228}$ second, that the obligation to ensure the serving of prison terms for war crimes should be stipulated, except for releases of prisoners for criminal policy, ${ }^{229}$ and third, reparation from the stocks of Japanese gold should be made available as an alternative to reparations from facilities. ${ }^{230}$

The soft peace of the United Kingdom was created based on Japanese responsibility for the war and obviously denied amnesty and non-reparation as advocated in positivism. These legal effects of British soft peace were crucially distinct from American soft peace that recognized the centrality of the principle of no reparation from the perspective of realism.

On January 12, 1951, Dulles, Consultant to the Secretary of State, restated the commitment to soft peace of the United States in a revised 7-point Memorandum, known as the 8-point Memorandum, that he delivered to Oliver S. Franks, Ambassador of the United Kingdom. Dulles stated that "the United States, therefore, proposed a simple, non-punitive treaty, with no post-treaty controls, which will bring Japan quickly back into a position of complete sovereignty among the other nations." ${ }^{231}$ The revised memorandum laid down the same goals as the "Draft of a Peace Treaty with Japan" of September 11, 1950, which had not yet been given to the United Kingdom, including the joint right to grant amnesty (paragraph 6) and the waiver of claim for reparation (paragraph 7). ${ }^{232}$ The American soft peace violently conflicted with the British version of soft peace.

\subsection{Alliance between the United States and Japan}

Through independent negotiations with Japan, the United States adjusted the legal effects of its soft peace to harmonize with Japan's position. On January 30, 1951, Shigeru Yoshida, prime minister and Minister for Foreign Affairs of Japan concurrently, set forth his views to Dulles and MacArthur. Yoshida made a plea for no reparation from current production or in money, no more new war crime trials, and an amnesty on the occasion of the conclusion of the peace treaty. ${ }^{233}$ In this way, Japan appealed to the United States, which placed great

\footnotetext{
226 The United Kingdom adopted soft peace at almost the same time as the United States, whether their version of the concept had adequate substance. The reason for this examination was also the transition to soft peace in the United Kingdom; and the memorandum by Morrison of May 23, 1951 that said, "The general effect of the talks seems to have been to clear up the atmosphere and dispel certain suspicions which were beginning to form on the United States side to the effect that, despite our protestations to the contrary, we might in fact be trying either to delay the Peace Treaty or to give it a restrictive and illiberal character. The talks seem to have convinced the United States Government that in this important Far Eastern matter it was possible for British and Americans to work together as a team." (Memorandum by the Secretary of State for Foreign Affairs (C.P. (51) 137, the United Kingdom National Archives). p. 2).

227 “His Majesty's Government's major object in the Peace Treaty discussions should be to secure a treaty which will permit the development of a peace-loving Japan with a viable economy." See, Japanese Peace Treaty: General (C.P. (50) 323, the United Kingdom National Archives). p. 2.

228 "A reference to the responsibility of the Japanese militarist régime for having provoked a state of war, in terms similar to those used in the Italian Peace Treaty, should be included in the Preamble." See, ibid., pp. 3, 8.

229 "An obligation should be laid upon the Japanese Government to ensure that, subject to normal remissions for good conduct, war criminals in Japan sentenced to terms of imprisonment before the Peace Treaty should serve the prison terms to which they were sentenced by War Crimes Courts." See, ibid.

230 "It was agreed...that no further reparations should be exacted from Japanese industrial assets. His Majesty's Government should, however, press for the stocks of Japanese (monetary) gold, under the control of the Supreme Commander in Japan to be made available as reparations. It must, however, be recognised that such a suggestion will be strongly resisted by the United States Government.”; “( $e$ ) It was agreed that it would be unrealistic to contest the American view that reparations from industrial assets should be regarded as a dead issue. $(f)$ But it was not accepted that His Majesty's Government should abandon their claim to Japanese gold. We should resist the American claim to use Japanese gold to pay occupation costs..." See, ibid., pp. 3, 5 .

${ }^{231}$ Memorandum of Conversation, by the Special Assistant to the Consultant (Allison). In [1951] FRUS (vol. 6). p. 793.

${ }^{232}$ Ibid., pp. 796-797.

${ }^{233}$ Wagahō kenkai [Yoshida's views]. In DJFP: Negotiation with the US. pp. 182-183, 187-188 (in English and Japanese).
} 
emphasis on soft peace, to grant legal effects similar to those of a positivist's concept of peace as in the two documents of October 4, 1950.

Dulles responded to these views in talks with Yoshida on January 31, 1951 expressing agreement with Japanese proposals on reparation and war crime trials; but rejecting general amnesty for war criminals and suggested case-by-case decisions. ${ }^{234}$ The United States' position toward no reparation and limited amnesty reflected the draft of the Treaty of Peace with Japan of September 11, 1950 and the 8-point Memorandum of January 12, 1951, which the Japanese government had not yet seen.

On February 5, a provisional memorandum prepared by Dulles Mission from February 3, which included the exercise of the power to grant amnesty ${ }^{235}$ and the waiver of claims, ${ }^{236}$ was handed to Japan. ${ }^{237}$ This was the first time the Japanese government was acquainted with the specific contents of the peace treaty based on soft peace as put forward by the United States. The following day at administrator level negotiations, Japan expressed its opinions on the provisional memorandum of the United States. ${ }^{238}$ The statement said, "It is desired that a clause be inserted, putting an end to prosecution of new cases." ${ }^{239}$

However, at the talks between Yoshida and Dulles on February 7, Dulles made a remark that there would be no need to add a provision for ending prosecution because new war crime trials were tacitly not allowed and Yoshida agreed with this. ${ }^{240}$ Thus, one of the legal effects of amnesty in the Treaty of Peace with Japan was prohibition of new prosecutions. On February 9, as a consequence of initialing the provisional memorandum of February $3,{ }^{241}$ the United States aligned Japan with the soft peace line of the United States.

\subsection{Feud between Two Concepts of Soft Peace}

Through interchanging aide-mémoires, the conflict between the two versions of soft peace of the United States and the United Kingdom was revealed. On January 29, 1951, Dulles and Alvary Gascoigne, Political Representative of the British Liaison Mission to SCAP, held conversations in Tokyo, where Ambassador Gascoigne read aloud an informal statement of the current thinking of the United Kingdom on the Japanese peace treaty and their intent to include some type of war-guilt clause and claims for damage to be completely met by Japan. ${ }^{242}$ It appeared that superficial soft peace and virtual harsh peace were unchanged for the United Kingdom.

Therefore, the United Kingdom claimed that it had superficially adopted soft peace in the aide-mémoire of March 12, which was introduced to the United States. This mémoire offered legal effects substantively based on

${ }^{234}$ Yoshida Dulles kaidan (dai ni kai) [The talks between Yoshida and Dulles (the second time)]. In DJFP: Negotiation with the US. p. 192 (in Japanese).

235 “( $(e)$ The power to grant clemency, reduce sentences, parole and pardon with respect to war criminals incarcerated in Japan would be exercised jointly by Japan and the Government or Governments which imposed the sentences in each instance and, in the case of persons sentenced by the International Military Tribunal for the Far East, by Japan and a majority of the Governments represented on the Tribunal." See, Memorandum Prepared by the Dulles Mission. In [1951] FRUS (vol. 6). p. 851.

236 "All parties would waive claims arising out of acts taken during the war prior to September 2, 1945, except that (1) each of the Allied and Associated Powers would retain and dispose of Japanese property within its territories, except diplomatic and consular property and a few other limited categories; and (2) Japan would restore, upon demand, Allied property in Japan, or, if such property, whether or not taken under the control of the Japanese Government, is not restorable intact, would provide yen to compensate for the lost value...”; “...The Allies would demand no reparations either out of the industrial assets, current production or gold stocks..." See, ibid., pp. 852, 853.

${ }^{237}$ Kari oboegaki an [Provisional memorandum]. In DJFP: Negotiation with the US. p. 229, 229, n. 1 (in Japanese).

${ }^{238}$ Nichibei jimu reberu sesshō (dai yon kai) [Japan-the United States negotiation at administrator level (the fourth time)]. In DJFP: Negotiation with the US. p. 239 (in Japanese).

${ }^{239}$ Kari oboegaki an ni taisuru wagahō no iken oyobi setsumon [Japanese opinions and questions about the provisional memorandum]. In DJFP: Negotiation with the US. pp. 250-251 (in English and Japanese).

${ }^{240}$ Yoshida Dulles kaidan (dai san kai) [The talks between Yoshida and Dulles (the third time)]. In DJFP: Negotiation with the US. p. 256 (in Japanese).

${ }^{241}$ Kari oboegaki nado go bunsho he no inishiaru ni tsuite [On initialing five documents such as the provisional memorandum]. In DJFP: Negotiation with the US. pp. 266-280 (in English and Japanese).

${ }^{242}$ Editorial Note. In [1951] FRUS (vol. 6). pp. 825-827; Memorandum by Mr. Robert A. Fearey of the Office of Northeast Asian Affairs. In [1951] FRUS (vol. 6). pp. 830-832. 
harsh peace as akin to the "Japanese Peace Treaty: General" of December 19, 1950, which the United States had not seen yet. Whereas the United Kingdom adopted soft peace on the surface by means of maintaining that the object of a Japanese peace treaty should be to establish a peace-loving Japan with a settled government and a viable economy, ${ }^{243}$ the United Kingdom contended that a reference to the responsibility of Japan for the war similar to the Italian Peace Treaty should be included in the preamble. ${ }^{244}$

Moreover, with respect to war criminals, the United Kingdom wanted an obligation to ensure that war criminals served the sentences imposed by war crime trials, which should be laid upon Japan. ${ }^{245}$ Furthermore, the United Kingdom persisted in scheming for reparation with a clever trick, replacing the resources of reparation by dodging through loopholes in the 7-point and 8-point Memoranda of the United States. The United Kingdom attempted to convince the United States that reparation from the stocks of Japanese gold should be made available as an alternative to reparation from facilities. ${ }^{246}$ These legal effects, which absolutely denied an amnesty in the peace treaty and tenaciously required reparation from gold, significantly differed from the United States' version of legal effects that restrictively permitted the Japanese government to grant amnesty and adhered to the principle of no reparation.

As a natural reaction to these dissimilarities, the United States addressed an aide-mémoire on March 14 to the United Kingdom and declared against the legal effects of the United Kingdom's version of soft peace. Yet, the United States agreed with the statement in the aide-mémoire of the United Kingdom concerning the major objectives of the peace treaty with Japan. ${ }^{247}$ However, the United States was of the opinion that there were several paragraphs in the United Kingdom's aide-mémoire that were inconsistent with the agreed upon objectives of the peace treaty. ${ }^{248}$

Accordingly, the United States critiqued the soft peace of the United Kingdom. Regarding the war guilt clause, the United States strongly objected to this clause and stressed its uselessness in soft peace comparing it to the Versailles Peace Treaty. ${ }^{249}$ On the subject of war criminals, the United States reaffirmed that the Japanese government would not be allowed to grant amnesty without its joint exercise with the allied nations. ${ }^{250}$ The United States restated the necessity of a constrained amnesty in the peace treaty and emphasized that the Japanese obligation to ensure the serving out of prison terms led to a contradiction to soft peace. Finally, with regard to reparation, the United States expressed abhorrence at the United Kingdom's attitude disregarding the principle of no reparation in soft peace by a dissent against any reparation out of the stocks of Japanese gold. ${ }^{251}$ In conclusion, the analyses in this chapter have illustrated the collision of two versions of soft peace.

\section{Compromise between Two Concepts of Soft Peace}

\subsection{Peace Process between Two Concepts of Soft Peace}

Both the United States and the United Kingdom took measures to adjust their remarks through diplomatic negotiations as they groped for a compromise with each other's substantially irreconcilable concepts. On March 21, 1951, the United States and the United Kingdom held conversations to reduce their differences of opinions in

\footnotetext{
${ }^{243}$ The British Embassy to the Department of State. In [1951] FRUS (vol. 6). pp. 910.

${ }^{244}$ Ibid., p. 911.

245 Ibid.

${ }^{246}$ Ibid., p. 912. This policy of the United Kingdom toward the reparation from gold appeared to be theoretically supported as follows:

“...His Majesty's Government wish to take this opportunity of stating their view that in no circumstances should these stocks of gold be returned to Japan since they consider that the Allied and Associated Governments should not be asked to sacrifice the small and wholly inadequate amount of reparations which they might receive in this manner in order to give to Japan an appreciably better start as a free country than the victims of her aggression in the second world war." See, ibid.

${ }^{247}$ The Department of State to the British Embassy. In [1951] FRUS (vol. 6). p. 921.

${ }^{248}$ Ibid., p. 922.

249 "With respect to a 'war guilt' clause the United States doubts that it would accomplish any positive good, and if the Versailles analogy has relevance, it might do harm." See, ibid.

250 "With reference to the position enunciated by the United Kingdom regarding the serving of war crimes sentences, the United States believes that the Japanese Government should not be able to reduce or alter the sentences of war criminals unless by agreement with the nation or nations imposing the sentence." See, ibid.

${ }^{251}$ Ibid., p. 923.
} 
the form of memoranda of March 12 and 14. In the conversations, Robert H. Scott, Undersecretary of the Foreign Office of the United Kingdom, struck a compromise with the soft peace of the United States by stating that the British Foreign Office itself did not feel strongly about the point of including a war guilt clause in the treaty. ${ }^{252}$ However, regarding reparations from the gold stocks in Tokyo, the two allied powers remained at odds. Scott implied that the United Kingdom held to the demand for reparation from Japanese gold for fear that the British government would be attacked at home on the grounds that the Japanese treaty was too liberal; however, John M. Allison, Deputy to Ambassador Dulles, held to the United States' position and refuted the British view. ${ }^{253}$

Thereupon, on March 23, 1951, the United States presented the United Kingdom with a "Provisional Draft of a Japanese Treaty," drafted by modifying clauses stipulated in the 8-point Memorandum. ${ }^{254}$ The United States expressed a tendency toward compromise on both punishment and reparation. First, while Japan would still be jointly entitled to grant amnesty, the United States hinted that in principle, the power to grant amnesty should not be exerted by means of adopting a negative sentence, which said that it "may not be exercised." 255 Thus, the provision for war criminals formally approached British soft peace, which demanded serving out their terms in prison, with American soft peace substantially preserved. Second, the United States took into consideration the remarks of the United Kingdom and its persistent claim for reparation. The March 23 draft eliminated abandonment of the right to reparation and stipulated a mere recognition by the allied powers of Japan's incapability to make reparation. ${ }^{256}$

These outcomes of mutual compromise by two major allied parties were reported by Allison on April 5 noting that the responsibility of the Japanese militarist régime and problem of reparation from Japanese gold stocks remained as points of difference. ${ }^{257}$

\subsection{Substantial Soft Peace of the United Kingdom}

The compromise of soft peace was accomplished by great concessions by the United Kingdom to the United States. A British provisional draft of the Treaty of Peace with Japan handed to the United States on April 9, $1951^{258}$ had been prepared since at least February. ${ }^{259}$ Therefore, it did not consider the aide-mémoire of March 14, nor the provisional draft of March 23 by the United States. ${ }^{260}$ Although the British government entirely agreed with the United States about the need to give the peace treaty a non-restrictive character and the framework for a liberal type of settlement of difficulties, ${ }^{261}$ the British provisional draft inserted a war guilt clause into the preamble, ${ }^{262}$ never allowed Japan to grant pardon for convicts, except measures to grant

${ }^{252}$ Memorandum of Conversation, by the Second Secretary of the Embassy in the United Kingdom (Marvin). In [1951] FRUS (vol. 6). p. 937.

${ }^{253}$ Ibid., p. 938.

${ }^{254}$ Shigeru Yoshida, prime minister and Minister of Foreign Affairs of Japan, received this draft from Ambassador Sebald on March 27, 1951. See, Heiwa jōyaku an [Provisional draft of a Japanese peace treaty]. In DJFP: Negotiation with the US. pp. 333-347 (in English and Japanese).

255 "12. The power to grant clemency, reduce sentences, parole and pardon... may not be exercised except jointly by Japan and the Government or Governments which imposed the sentence in each instance...” See, Provisional United States Draft of a Japanese Peace Treaty. In [1951] FRUS (vol. 6). p. 947.

256 "14. The Allied Powers recognize that Japan lacks the capacity to make payments in bullion, money, property or services... and also to make adequate reparation to the Allied Powers for war damage... Reparations claims of the Allied Powers and their claims for direct military costs of occupation shall be deemed to be satisfied out of the Japanese assets subject to their respective jurisdictions in accordance with the foregoing and out of assets received from the Japanese home islands during the occupation." See, ibid., pp. 948-949.

${ }^{257}$ The Deputy to the Consultant (Allison) to the Consultant to the Secretary (Dulles). In [1951] FRUS (vol. 6). p. 963.

${ }^{258}$ See, Memorandum by the Secretary of State for Foreign Affairs (C.P. (51) 104, the United Kingdom National Archives). p. 1.

${ }^{259}$ FO371/92532 (the United Kingdom National Archives). See especially, pp. 67-123.

${ }^{260}$ Mr. Morrison to Sir O. Franks (Washington) (FJ 1022/222). Reprinted in C.P. (51) 104 (the United Kingdom National Archives). p. 6.

261 Ibid.

262 "Whereas Japan under the militarist régime became a party to the Tripartite Pact with Germany and Italy, undertook a war of aggression and thereby provoked a state of war with all the Allied and Associated Powers and with other United Nations, and bears her share of responsibility for the war" See, Provisional Draft of Japanese Peace Treaty (United Kingdom). Reprinted in C.P. (51) 104 (the United Kingdom National Archives). p. 8. 
clemency or to commute from the perspective of criminology, ${ }^{263}$ and provided an obligation of Japan for transfer gold, bullion, precious metals, and jewels as reparation. ${ }^{264}$

In this way, the draft of the Treaty of Peace with Japan of the United Kingdom stipulated legal effects, which inclusively and substantially paralleled harsh peace. Thus, on April 23, Dulles criticized this draft for its contents so repellant to the Japanese nation, ${ }^{265}$ implying that the draft did not conform to the soft peace of the United States.

However, on April 16, Herbert Stanley Morrison, the Secretary of State for Foreign Affairs of the United Kingdom, made significant appeasement by accepting several views of the United States in a memorandum and the document named the "Substance of the Treaty," which was not presented to the United States. In light of the United States' attitude, it stated that the British government should not seek to secure a reference in the treaty to the responsibility of the Japanese militarist régime for having provoked a state of war. ${ }^{266}$ What is more, it recommended that the provision for war criminals proposed by the United States should be accepted; however, the term "pardon" should be strongly resisted since convicted war criminals could not be granted pardon under any circumstances except by due process of law. ${ }^{267}$ Lastly, it admonished that in accepting the view of the United States, the British government should no longer insist that stocks of Japanese gold should be made available as reparation. ${ }^{268}$ Accordingly, the compromise of soft peace succeeded because of significant concessions by the British to the United States, except for the word "pardon."

\subsection{Japan's Antipathy against Superficial Soft Peace}

The Japanese government, which was unaware of the concessions made by the United Kingdom, was appalled at the soft peace of the British government. At the outset, the draft of the United Kingdom was drafted for a peace cognate with the Italian Peace Treaty, which was imposed upon a defeated nation by victorious powers. To the Japanese government, that draft equaled a treaty of dictated peace, that is, harsh peace. ${ }^{269}$

On April 20, 1951, Japan presented the document, "Observations on the British Draft Peace Treaty for Japan" to William J. Sebald, Ambassador of the United States. It stated that the character of the British peace treaty draft was one to be imposed by the victor on the vanquished who had unconditionally surrendered. Therefore, it was a

263 "Japan undertakes to accept the judgments and carry out the orders of the International Military Tribunal for the Far East, and of all other duly constituted Allied War Crimes Courts both within and outside Japan, respecting convictions and sentences imposed upon Japanese nationals. The power to grant clemency, reduction of sentences, and parole, shall, in the case of Japanese nationals sentenced by the International Military Tribunal for the Far East, be exercised jointly by the Government of Japan and a majority of the Governments represented on the Tribunal; and in the case of war criminals sentenced by any other of the above-mentioned War Crimes Courts and undergoing punishment in Japan, shall be exercised jointly by the Government of Japan and the Government or Governments which constituted the Courts having imposed the sentences in each instance.” See, ibid., p. 16.

264 "In addition to the sums already paid by her as reparation under approved Allied directives, Japan shall, within one year from the coming into force of the present treaty, transfer as reparation for the losses and suffering inflicted on the Government and nationals of the Allied and Associated Powers during the war, the stocks of monetary gold and bullion and of precious metals and jewels..." See, ibid.

${ }^{265}$ Yoshida Dulles kaidan (dai ni kai) [The talks between Yoshida and Dulles (the second time)]. In DJFP: Negotiation with the US. p. 408 (in Japanese).

${ }^{266}$ C.P. (51) 104 (the United Kingdom National Archives). p. 2; The Substance of the Treaty. Reprinted in C.P. (51) 104 (the United Kingdom National Archives). pp. 43-44.

${ }^{267}$ C.P. (51) 104, supra note 266, p. 2; "There is, however, one suggestion in the United States proposal quoted above that appears to be wholly unacceptable. This is that war criminals should be eligible to receive a pardon. The word may have a different meaning in American law, but in England it could only mean that a war criminal would not only be released but that his conviction would be set aside. It is suggested that it would be most objectionable to provide in the Peace Treaty that any properly convicted war criminal could in any circumstances have his conviction reversed except by due process of law...It is therefore recommended that the suggestion put forward by the United States Government that the Treaty should contain provision for the association of the Allied Governments concerned with grants of clemency, parole, \&c. to war criminals serving their sentences in Japan should be accepted, but that the proposal that the word 'pardon' should appear in the Article should be strongly resisted." The Substance of the Treaty, supra note 266, p. 45. Thus the term "pardon" in the United Kingdom has an identical meaning for amnesty for convicts in a peace treaty in that their convictions will be invalidated.

${ }^{268}$ C.P. (51) 104, supra note 266, p. 2; The Substance of the Treaty, supra note 266, p. 46.

${ }^{269}$ Eikoku no heiwa jōyaku an ni tsuite [On the British provisional draft of the Treaty of Peace with Japan]. In DJFP: Negotiation with the US. p. 374 (in Japanese). 
repetition of the mistake of the Versailles Peace Treaty, and that the preamble and Article 23, which stipulated the responsibility of Japan for provoking the war, and reparation from bullion, precious stones, and so forth, respectively, were totally unnecessary; therefore, the American draft was more realistic and preferable. ${ }^{270}$ Thus, Japan stressed afresh that the draft of the United Kingdom was a peace treaty based on harsh peace as in the Versailles Peace Treaty.

On the following day, Kumao Nishimura, Director of the Bureau of Treaties of the Ministry of Foreign Affairs of Japan, and Robert A. Fearey, Secretary of the Dulles Mission of the Department of State of the United States, held conversations on the British draft. Going article by article, Nishimura communicated the Japanese opinion that the British draft should be opposed, not only because of the inexpedient preamble with its war guilt clause, but because Japan hoped to repel the potentiality for manifold reparations in the hopes of adopting the principle of no reparation, which accepted that all claims arising from the war should be satisfied out of the disposition of Japanese property within the allied nations, as in the provisional draft of the United States of March 23, $1951 .{ }^{271}$

Japan was relying on the soft peace of the United States. In the interim on April 14, the Japanese government prepared a memorandum to the United States affirming and moving toward an enlargement of American soft peace as much as possible by petitioning that reparation claims be satisfied out of Japanese assets already in the hands of the Allies and should be construed as covering not only claims ascribed to direct actions in combat but also all claims arising out of the war. ${ }^{272}$

\section{Rigorous Soft Peace}

\subsection{Withdrawal of the Principle of No Reparation}

The United States, which had advocated for soft peace with a principle of no reparation as one of the most basic elements, eventually, receded from this principle and embraced the doctrine that Japan should make some reparation transforming American soft peace into a more rigid one. At the talks between Dulles and Yoshida on April 18, 1951, Dulles proposed that it would be good business for Japan to offer reparations from current production, which he had contradicted before, subject to the conditions in the Italian Peace Treaty. ${ }^{273}$ Accordingly, the principle of no reparation perished, making the soft peace of the United States somewhat more rigorous. $^{274}$

\footnotetext{
${ }^{270}$ Eikoku no heiwa jōyaku an ni taisuru wagahō iken [Observations on the British Draft Peace Treaty for Japan]. In DJFP: Negotiation with the US. pp. 388-392 (in English and Japanese).

${ }^{271}$ Eikoku no heiwa jōyaku an ni taisuru wagahō no chikujō teki kenkai ni tsuite [On commentary of the government of Japan on the British draft of the Treaty of Peace with Japan]. In DJFP: Negotiation with the US. pp. 397, 401 (in Japanese). It is noteworthy that, in the documents of April 17 and 21, 1951, Japan analyzed the provision for war criminals in the British draft as the article possessing the identical purport with the American draft. See, ibid., p. 400; Eikoku no heiwa jōyaku an ni tsuite [On the British provisional draft of the Treaty of Peace with Japan], supra note 269, p. 376. However, as mentioned above, there was an inevitable conflict between the United States and the United Kingdom over the term "pardon." Accordingly, it was Japan's fault for failing to take into account the elimination of "pardon" in the draft by the United Kingdom.

${ }^{272}$ Heiwa jōyaku sōan ni kansuru wagahō no taibei yobō jikō an [Draft of Japanese requests to the United States with regard to the American provisional draft of the Treaty of Peace with Japan]. In DJFP: Negotiation with the US. p. 368 (in Japanese).

${ }^{273}$ Memorandum of Conversation, by Mr. Robert A. Fearey of the Office of Northeast Asian Affairs. In [1951] FRUS (vol. 6). p. 987.

274 This attitude of the United States cannot be deemed as retrogression to harsh peace, for no provisions for a concrete obligation of Japan to make reparation could be observed in any of the drafts of the Treaty of Peace with Japan prepared by the United States which had excluded the principle of no reparation. In other words, there were stipulations in these drafts that Japan would merely enter into negotiations with the Allies for reparation by means of services. Moreover, in respect to legal effects based on a positivist's concept of peace which are analogous with soft peace, reparation was permitted as an exception despite the principle of no reparation. Thus, the disappearance of the principle of no reparation here means conversion not into providing obligation to make reparation as responsibility for waging war, as in the Versailles Peace Treaty, but into stipulating an exception to this principle. Because of this, the United States only determined to make soft peace more severe by focusing upon the exception to the principle of no reparation based on this concept. "Commentary on the draft of the Treaty of Peace with Japan" drawn by the Ministry of Foreign Affairs of Japan serves as one authority on these aforementioned considerations. In this commentary, the Treaty of Peace with Japan was defined as a treaty of reconciliation that was more lenient and righteous than every other peace treaties in the past. Therefore, it stated that no articles providing retributive reparation or concrete obligations to make reparation were stipulated in this treaty. See, Nihon koku to no heiwa jōyaku sōan no kaisetsu [Commentary on the draft of the Treaty of Peace with Japan]. In DJFP: Negotiation with the US. pp. 670-671, 688 (in Japanese). Additionally, the observations of December 10, 1951 handed to Ambassador Dulles on December 13, 1951 differentiated with respect to reparation between the Versailles Peace Treaty, the Italian peace
} 
However, in the second round of talks on April 23, Yoshida replied that Japan had not yet arrived at a concrete plan for reparation from current production, and expressed a desire for reparation by means of services stating that the government wished to advance a proposal for Japan to salvage and turn over to the Philippine government a considerable number of Japanese ships that sunk in Philippine waters. ${ }^{275}$ Because the United States was at odds with Japan on this topic, the resolution of the matter of reparation was postponed.

\subsection{Elimination of Japan's Right to Grant Amnesty to Convicted War Criminals}

On May 3, 1951, a "Joint United States-United Kingdom Draft Peace Treaty" provided only that the allied powers recognized the incapability of Japan to make sufficient reparation in the identical fashion as the provisional draft of the United States of March 23. ${ }^{276}$

In this draft, the position on war criminals was further stringent in two ways. First, as a consequence of considering the adamant objection of the United Kingdom against the term "pardon," in this draft "pardon" was restricted to being granted only when new evidence was discovered. ${ }^{277}$ Thus, unlimited amnesty in peace treaties for the convicted, which granted pardon to all war criminals in prison without any necessary conditions, could never be explicitly permitted in this draft. Second, Japan was not entitled to exercise the power to grant amnesty, but was only capable of making recommendations to the Allies for exertion of their authority. ${ }^{278}$ Therefore, Japan was not allowed to jointly possess the right to grant amnesty. In short, the United States and the United Kingdom deprived Japan of the right to grant amnesty notwithstanding an absence of the power to grant full amnesty for the convicted. The attitude of these two powers was more rigorous than the position advanced by the United Kingdom in the Morrison's memorandum of April 16, which recognized Japanese joint possession of the right to grant amnesty except pardon. Thus, for both the United States and the United Kingdom, soft peace was becoming more rigid. ${ }^{279}$

treaty, and the Japanese peace treaty, and stated that the formula for reparation had undergone three stages in this order. See, Yoshida Dulles kaidan no tame no sōri yō junbi shiryō [Preparatory observations for the Prime Minister of Japan for the talks between Yoshida and Dulles]. In Ministry of Foreign Affairs of Japan. (Ed.). (2009). Documents on Japanese Foreign Policy: Treaty of Peace with Japan Signing and Entry into Force. Tokyo: Ministry of Foreign Affairs of Japan (hereinafter DJFP: Signing and Entry into Force). p. 315 (in English and Japanese). It should be construed that reparation by services prescribed in the Treaty of Peace with Japan were distinguished from monetary reparation in the Versailles Peace Treaty and reparation from current production in the Peace Treaty with Italy; and were the most liberal formula of reparation of the three sorts. This also demonstrated that soft peace, as the lenient concept of peace, provided the theoretical basis for reparation by services in the Japanese peace treaty.

275 Memorandum of Conversation, by Mr. Robert A. Fearey of the Office of Northeast Asian Affairs. In [1951] FRUS (vol. 6). p. 1007. See, also, Firipin no baishō yōkyū ni taisuru wagahō taisho hōshin [Japanese policy toward the Philippines' claim to reparation]. In DJFP: Negotiation with the US. pp. 412-413 (in English and Japanese).

276 Joint United States-United Kingdom Draft Peace Treaty. In [1951] FRUS (vol. 6). pp. 1031-1032.

277 "The power to grant clemency, reduce sentences, parole and pardon (the last only when newly discovered evidence so warrants)..." See, ibid., pp. 1028-1029.

278 "The power to grant clemency, reduce sentences, parole and pardon...may not be exercised except on the decision of the Government or Governments which imposed the sentence in each instance, and on the recommendation of Japan. In the case of the persons sentenced by the International Military Tribunal for the Far East, such power may not be exercised except on the decision of a majority of the Governments represented on the Tribunal, and on the recommendation of Japan." See, ibid.

279 As with reparation, these modifications on the power to pardon by the two allied nations cannot be evaluated as retrogression to harsh peace because the draft of May 3 and the other drafts of the Treaty of Peace with Japan did not include any specific provisions for extinguishing all legal effects of amnesty in a peace treaty, although prosecution of new cases was not allowed tacitly in accordance with one of those effects from the standpoint of soft peace of the United States as discussed earlier. Accordingly, given the fact that the exception to amnesty in a peace treaty was permitted in a positivist's concept of peace which was analogous to soft peace, the provision of this draft, which full amnesty in a peace treaty was deprived only of convicted criminals, was as an exception to the principle of amnesty. Both the United States and the United Kingdom made their concepts more rigorous than the before the negotiations. These interpretations conformed to most of the official explanation of the government of Japan. In a "Commentary on the draft of the Treaty of Peace with Japan" of the Ministry of Foreign Affairs of Japan, it was interpreted that Article 11 about war criminals was an exception to the provision that all convictions became invalid hereafter, unless the contrary was expressly stipulated, after taking effect of a peace treaty. See, Nihon koku to no heiwa jōyaku sōan no kaisetsu [Commentary on the draft of the Treaty of Peace with Japan], supra note 274, pp. 683-684 (in Japanese). This official explanation was ratified in the Diet of Japan. See, the statements of Kumao Nishimura, Director of the Bureau of Treaties of the Ministry of Foreign Affairs, at the meeting of October 17, 1951 of the special committee of the House of Representatives for the Treaty of 
On the other hand, this joint draft did not provide any articles or sentences indicating Japan's responsibility for the war. Thus, Morrison's memorandum of May 23 stated that the representatives of the United Kingdom reached an agreement with the United States on the omission of the war guilt clause, which had figured in the previous United Kingdom draft ${ }^{280}$ and with the result that the United Kingdom deferred to the soft peace of the United States in this regard. However, on the contents of the treaty, the United Kingdom held sway on war criminals and reparation from Japanese gold, ${ }^{281}$ so that it succeeded in inhibiting these two matters in the joint draft of May 3. Nevertheless, stating that it should no longer insist that stocks of Japanese gold should be made available as reparation, ${ }^{282}$ the United Kingdom continued to try to reach a compromise with the United States on reparation out of the gold. This concession of the United Kingdom was communicated to the United States in conversations between Dulles and Morrison on June 13; accordingly, the United Kingdom agreed not to press its proposal for the distribution of Japanese gold as reparation. ${ }^{283}$ Eventually, the two powers arrived at a compromise that reparation from Japanese gold would not be exacted. On the question of reparation, the United Kingdom agreed with the soft peace of the United States.

\subsection{Insertion of Reparation from Services}

Although they had arrived at these compromises, the United States and the United Kingdom were nevertheless committed to making their soft peace more rigorous than their respective drafts mentioned in Chapter 6 with regard to punishment and reparation. Whereas no reference was included as to Japanese responsibility for provoking the war in accord with Morrison's memorandum of May 23, in the "Revised United States-United Kingdom Draft of a Japanese Peace Treaty" dated June 14, 1951, there were measures against war criminals and for reparation in more rigorous prescriptions than the previous soft peace of the United States or the weakened British soft peace.

First, regarding war criminals, the reference to Japanese explicit acceptance of the judgments of war crime trials was inserted; Japan was restricted to making recommendations to the allied parties for exercising their power to grant clemency and so forth as Japan was deprived of the right as in the joint draft of May 3. Moreover, pardons that could be granted only if new evidence was discovered as in the same draft was eliminated in United States concessions, so that the power to pardon itself was completely abated. ${ }^{284}$ This was a more oppressive imposition than the joint draft of May 3, which was already a more rigorous soft peace.

Second, on reparation, in addition to the recognition by the allied powers that Japan was not capable of making adequate reparation and the stipulation that allied parties could dispose of Japanese property in their territories in the same manner as in the joint draft of May $3,{ }^{285}$ the responsibility of Japan to make reparation was implied and the provision that Japan should enter into negotiations with the allied powers for reparation from services was inserted. ${ }^{286}$ Therefore, the view of making soft peace rigorous as the exception to the principle of no reparation,

Peace with Japan and the Security Treaty between Japan and the United States of America; and at the meeting of October 26, 1951 of the special committee of the House of Councilors for the Treaty of Peace with Japan and the Security Treaty between Japan and the United States of America. Furthermore, these interpretations can be corroborated by the fact that all convicted criminals with regard to China were released as a result of exclusion of the legal effect provided in Article 11 of the Treaty of Peace with Japan by Paragraph 1(c) of the Protocol of the Treaty of Peace between Japan and the Republic of China. Cf, Nicchū seijō kankei no settei ni kansuru kyōtei an yōryō [Draft Agreement concerning the Establishment of Normal Relations between the Government of Japan and the National Government of the Republic of China]. In DJFP: Signing and Entry into Force. pp. 351,353 (in English and Japanese).

${ }^{280}$ Memorandum by the Secretary of State for Foreign Affairs, supra note 226, p. 1.

${ }^{281}$ Ibid.

${ }^{282}$ Ibid., pp. 2, 17.

${ }^{283}$ Editorial Note. In [1951] FRUS (vol. 6). p. 1118.

284 “Japan accepts the judgments of the International Military Tribunal for the Far East and of other Allied War Crimes Courts both within and outside Japan, and will carry out the sentences imposed thereby upon Japanese nationals imprisoned in Japan. The power to grant clemency, reduce sentences and parole with respect to such prisoners may not be exercised except on the decision of the Government or Governments which imposed the sentence in each instance, and on the recommendation of Japan...” See, Revised United States-United Kingdom Draft of a Japanese Peace Treaty. In [1951] FRUS (vol. 6). p. 1123.

285 Ibid., pp. 1125-1126.

286 “...Japan should in principle pay reparation for the damage and suffering caused by it during the war...1. Japan will promptly enter into negotiations with Allied Powers so desiring, whose present territories were occupied by Japanese forces and damaged by Japan, with a view 
which had been postponed since April, was eventually actualized in this revised joint draft. However, the safeguard against rigorous soft peace was simultaneously prepared by stipulating that the allied powers waived all their reparation claims except as otherwise provided in this peace treaty. ${ }^{287}$

On June 25, John Moore Allison, Director of the Office of North East Asian Affairs of the United States, communicated to the Japanese government the final version of soft peace that resulted from the negotiations between the United States and the United Kingdom. Allison further clarified the final language on how war criminals would be managed explaining to the government of Japan: (1) the addition of the sentence stating that Japan would accept the judgments of war crime trials; (2) the elimination of Japan jointly possessing the power to grant clemency and so on; and (3) the acceptance of the new phrase, which provided that Japan could merely make recommendation to the Allies on decisions to grant clemency and so forth. ${ }^{288}$

Allison went on to emphasize that the United Kingdom, Australia, and Philippine strongly demanded some form of reparation, so he tried to convince Japan to assume some acts to restore damages so as to retrieve some favor with the allied powers without being insolvent. ${ }^{289}$ Allison further acquainted Japan with the fact that in the peace treaty, there would be reference to Japanese responsibility to make reparation and the provision that Japan would enter into negotiations with the allied powers for administration of reparation. ${ }^{290}$

On June 28 and 29, Allison delivered several provisions in the revised joint draft dated June 14, including revisions regarding war criminals and reparation. ${ }^{291}$ The Japanese government confirmed protocols, which represented rigorous soft peace. In response to the revised joint draft, Japan did not refute rigorous soft peace or call for abatement, but called upon the United States only to confine the point at which the allied powers would be able to dispose of Japanese property within their territories ${ }^{292}$ so that Japan could make every effort to secure a profit to a significant extent. Thus, with respect to war criminals and reparation, the "Draft Japanese Peace Treaty" dated July 3, given to Japan on July 7 and published on July 12 provided rigorous soft peace exactly as in the revised joint draft dated June 14, except for the restriction of the juncture for the disposal of Japanese property within the territories of the Allies at the request of Japan. ${ }^{293}$

\subsection{Determination of Rigorous Soft Peace}

One of the allied parties, the Philippine schemed for a much more rigorous soft peace or harsh peace. On July 12 , 1951, the government of Philippine which had already received the draft of July 3, proposed revisions to the provision on reparation seeking explicit obligation of Japan to pay reparation, and ignoring Japanese incapability to make sufficient reparation as well as the limitation of the means of reparation from services. ${ }^{294}$

Accordingly, the United States negotiated with the Philippines over the provision on reparation. The negotiation results were presented in a document of August 9. The United States claimed that any further discussions or proposals on monetary reparation currently or later would be utterly useless. However, the two states determined that the wording of the provision in the draft dated July 3 would be changed to locate the recognition of Japan's obligation to pay reparation at the front of the paragraph; but the other paragraph which provided negotiations between Japan and the Allies for reparation from services without any concrete obligations to repair remained

\footnotetext{
to assisting to compensate those countries for the cost of repairing the damage done, by making available the skills and industry of the Japanese people in manufacturing, salvaging and other services to be rendered to the Allied Powers in question..." See, ibid., p. 1125.

${ }^{287}$ Ibid., p. 1127

${ }^{288}$ Bei ei kōshō no kekka ni kansuru Allison no setsumei ni tsuite [On the explanation by Allison as to the result of the negotiations between the United States and the United Kingdom]. In DJFP: Negotiation with the US. p. 441 (in Japanese).

${ }^{289}$ Ibid., p. 439.

${ }^{290}$ Ibid., p. 441.

${ }^{291}$ Heiwa jōyaku no shūsei an bun [The revised draft of the Peace Treaty]. In DJFP: Negotiation with the US. pp. $466-478$ (in English and Japanese).

${ }^{292}$ Heiwa jōyaku no shūsei an ni taisuru wagahō iken [Japanese observations on the revised draft of the Peace Treaty]. In DJFP: Negotiation with the US. pp. 499-500, 503 (in English and Japanese).

${ }^{293}$ Heiwa jōyaku an oyobi sengen an (shichi gatsu mikka duke) [Draft Japanese Peace Treaty and Declaration of July 3]. In DJFP: Negotiation with the US. pp. 535, 538-540 (in English and Japanese).

294 The Ambassador in the Philippines (Cowen) to the Secretary of State. In [1951] FRUS (vol. 6). p. 1215, n. 2.
} 
unchanged. $^{295}$

Thus, the final texts of the Japanese Peace Treaty, which incorporated revisions to the draft texts of July $20,{ }^{296}$ were presented to Japan on August 15 and released for publication on August $16{ }^{297}$ These final texts mirrored the results of the negotiations between the United States and the Philippines and the articles for reparation in these texts began with the paragraph recognizing Japan's obligation to make reparation. ${ }^{298}$ The other paragraphs of these articles remained in the same order as in the draft of July $3^{299}$ and the article on war criminals also remained identical with the content in the draft of July $3 .^{300}$

John Foster Dulles conveyed that the adopting form of the paragraph with the first sentence being Japan formally recognizing its obligations for reparation appeared to Japan to be more superficially unfeeling; however, it was substantially identical to the preceding draft. ${ }^{301}$ In this way, the adoption of a much more rigorous soft peace or the retrogression to harsh peace, which the Philippines failed to achieve, left a rigorous soft peace drawn from adjustments to soft peace by the United States and the United Kingdom as the ultimate concept of peace that became the grounds of the Treaty of Peace with Japan.

In accordance with the drafting process analyzed and considered from Chapter 4 to this chapter, the Treaty of Peace with Japan was completed. To summarize the preliminaries, the allied powers started out with the traditional harsh peace as enacted in the Versailles Peace Treaty. Next, a conversion to soft peace emerged as a result of the commitment of the United States to diplomatic policies from the perspective of realism typified by George F. Kennan and John Foster Dulles. Third, the allied parties adjusted the legal effects based on soft peace, resulting in the Treaty of Peace with Japan based on a rigorous soft peace.

\section{Conclusion}

This study of the phenomenon of giving the incentive for arguments over legal rules and principles for post-conflict peace-making has been conducted based on empirical methodology as much as possible through the diachronic analyses of diplomatic negotiations in the processes of drafting the Versailles Peace Treaty and the Treaty of Peace with Japan. In conducting the analyses, the author has recognized the barometers, harsh peace and soft peace, and how they influenced the legal effects of post-war reparation and punishment which include:

(1) In the process of drafting the Versailles Peace Treaty, in the face of the antagonism between harsh peace and soft peace, the United States made concessions to the United Kingdom and France that brought about a conversion to harsh peace. Yet, the United States executed a strong foreign policy directed towards softening this concept, with the result that a moderated harsh peace was adopted as the concept of peace. (2) The adoption of harsh peace was maintained by related states in the infancy of the drafting process of the Treaty of Peace with Japan. (3) However, the United States shifted its focus to foreign policy founded in realism under the guidance of George F. Kennan, resulting in a cornerstone for the adoption of soft peace that was more cognizant of the realities of Japan and international politics than harsh peace. Being strongly influenced by the realism of the United States, the United Kingdom transitioned to soft peace. (4) With the entrance of John Foster Dulles into the process, the United States adopted soft peace that provided power to Japan to grant amnesty to convicted war criminals and the principle of no reparation as its legal effects, which were well received by the Japanese government. Although suggesting the adoption of this concept, the United Kingdom still substantially maintained that the peace treaty should be based on harsh peace. Hindsight reveals that the conversion of the United Kingdom to soft peace was only superficial. (5) The United States and the United Kingdom moved toward a

\footnotetext{
295 The Ambassador in the Philippines (Cowen) to the Secretary of State. In [1951] FRUS (vol. 6). p. 1251.

296 "Draft Treaty of Peace with Japan" of July 20, 1951 did not include any altered provisions with regard to war criminals or reparation. See, Heiwa jōyaku shichi gatsu mikka duke an to shichi gatsu hatsuka juryō an no hikaku [Comparison between Draft Japanese Peace Treaty of July 3 and Draft Treaty of Peace with Japan received on July 20]. In DJFP: Negotiation with the US. pp. 564-570 (in English and Japanese).

${ }^{297}$ Heiwa jōyaku oyobi sengen no saishū an kōhyō ni saishite no happyō bun [Press release for the publication of the final texts of the Japanese Peace Treaty and Declarations]. In DJFP: Negotiation with the US. pp. 650-651 (in English and Japanese).

${ }^{298}$ Heiwa jōyaku sengen giteisho no saishū an [The final texts of the Japanese Peace Treaty, Declarations and Protocol]. In DJFP: Negotiation with the US. p. 631 (in English and Japanese).

${ }^{299}$ Ibid., pp. 631-638.

${ }^{300}$ Ibid., p. 628.

${ }^{301}$ Yoshida sōri naisō shiryō [Information for Prime Minister Yoshida as to confidential report to Emperor Hirohito]. In DJFP: Negotiation with the US. p. 663 (in Japanese).
} 
compromise on the legal effects based on their respective concepts of soft peace by making adjustments to their drafts through diplomatic negotiations. (6) In finalizing the legal effects of the Treaty of Peace with Japan, rigorous soft peace was adopted after the United States and the United Kingdom reversed their stands on no reparation, but still deprived the Japanese government of the power to grant amnesty to convicted war criminals.

These alterations of the barometers substantiate the existence of the diplomatic historical fact as the phenomenon that a concept of peace was fluctuated from harsh one into soft one on the way to drafting the Treaty of Peace with Japan, and was set for the directionality of making its nature of softness slightly rigid. Thus, in conclusion, one of the facets of the phenomenon yielding the incentive to the contemporary discussions on peace-making among international lawyers can be described as the fact, through the drafting process of the Treaty of Peace with Japan, that the methodology of providing the legal nature of sophisticated generosity tempered by a sternness was started to be adopted.

\section{Copyrights}

Copyright for this article is retained by the author(s), with first publication rights granted to the journal.

This is an open-access article distributed under the terms and conditions of the Creative Commons Attribution license (http://creativecommons.org/licenses/by/3.0/). 